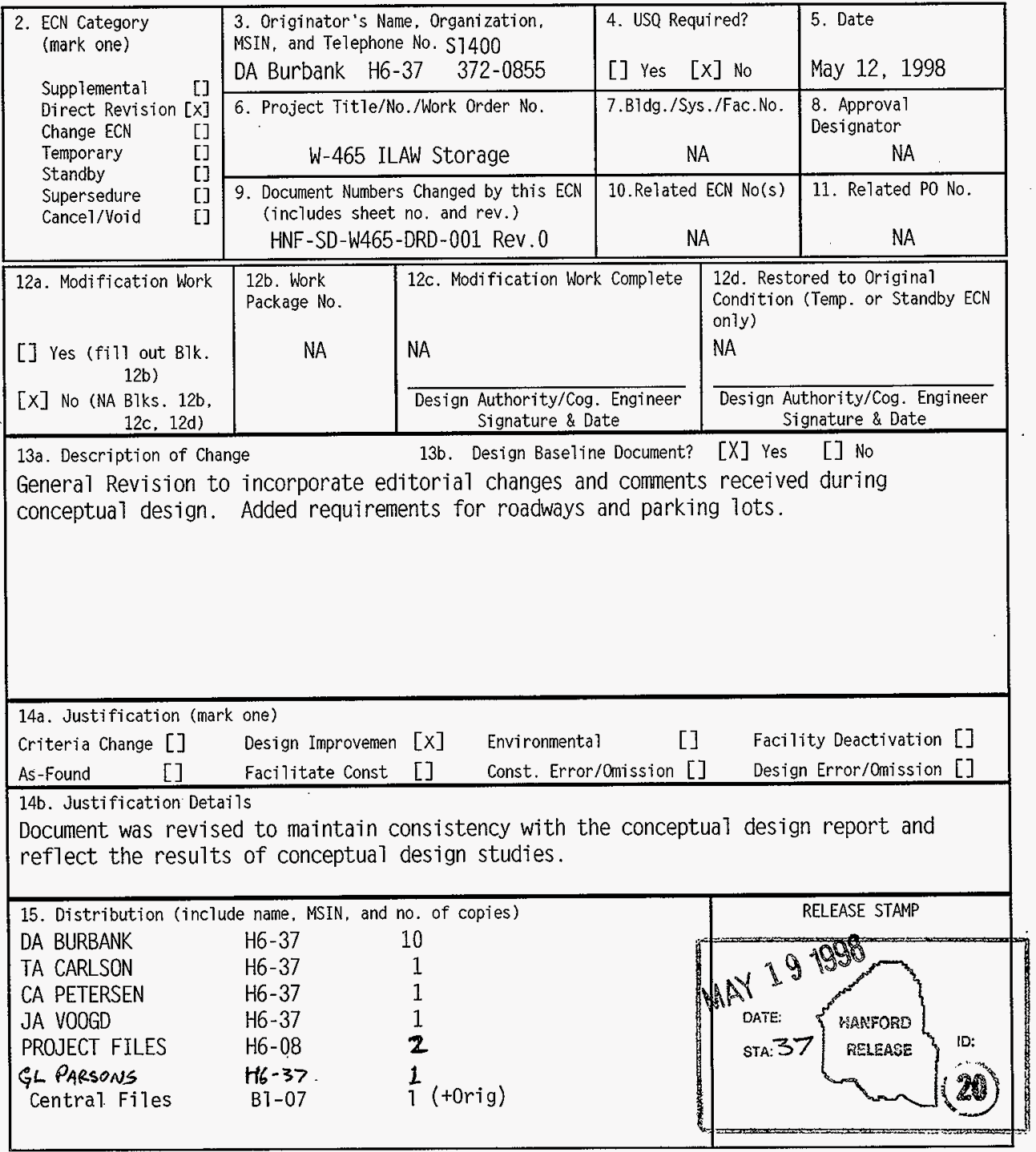




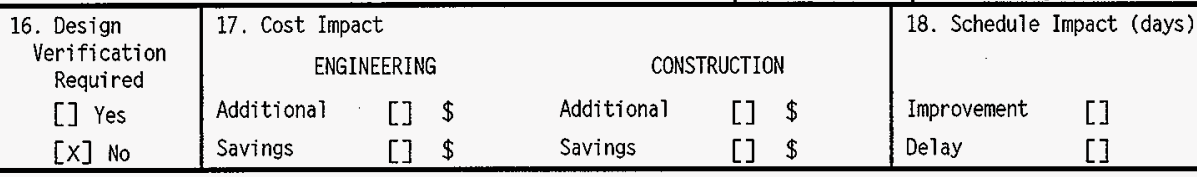

19. Change Impact Review: Indicate the related documents (other than the engineering documents identified on Side 1) that will be affected by the change described in Block 13. Enter the affected document number in Block 20.

\begin{tabular}{|c|c|c|c|c|}
\hline SOD/DD & {[]} & Seismic/Stress Analysis & [] & Tank Calibration Mamual \\
\hline Functional Design Criteria & {[]} & Stress/Design Report & [] & Health Physics Procedure \\
\hline Operating Specification & [] & Interface Control Drawing & [] & Spares Multiple Unit Listing \\
\hline Criticality Specification & {[]} & Calibration Procedure & [] & $\begin{array}{l}\text { Test } \\
\text { Procedures/Specification }\end{array}$ \\
\hline Conceptual Design Report & [] & Instal lation Procedure & [] & Component Index \\
\hline Equipment Spec. & {[]} & Maintenance Procedure & [] & ASME Coded Item \\
\hline Const. Spec. & {[]} & Engineering Procedure & [] & Human Factor Consideration \\
\hline Procurement Spec. & [] & Operating Instruction & [] & Computer Software \\
\hline Vendor Infomation & {[]} & Operating Procedure & [] & Electric Circuit Schedule \\
\hline OM Manual & {[]} & Operational Safety Requirement & [] & ICRS Procedure \\
\hline FSAR/SAR & [] & IEFO Drawing & [] & Process Control Manual/Plan \\
\hline Safety Equipment List & [] & Cell Arrangement Orawing & [] & Process Flow Chart \\
\hline Radiation Work Permit & {[]} & $\begin{array}{l}\text { Essential Material } \\
\text { Specification }\end{array}$ & [] & Purchase Requisition \\
\hline Environmental Impact Statement & {[]} & Fac. Proc. Samp. Schedule & [] & Tickler File \\
\hline Envirormenta] Report & [] & Inspection Plan & {[]} & \\
\hline Environmenta] Pernit & {[]} & Inventory Adjustment Request & [] & \\
\hline
\end{tabular}

20. Other Affected Documents: (NOTE: Documents listed below will not be revised by this ECN.) Signatures below indicate that the signing organization has been notified of other affected documents listed below. Document Number/Revision Document Number/Revision Document Number Revision NA

21. Approvals

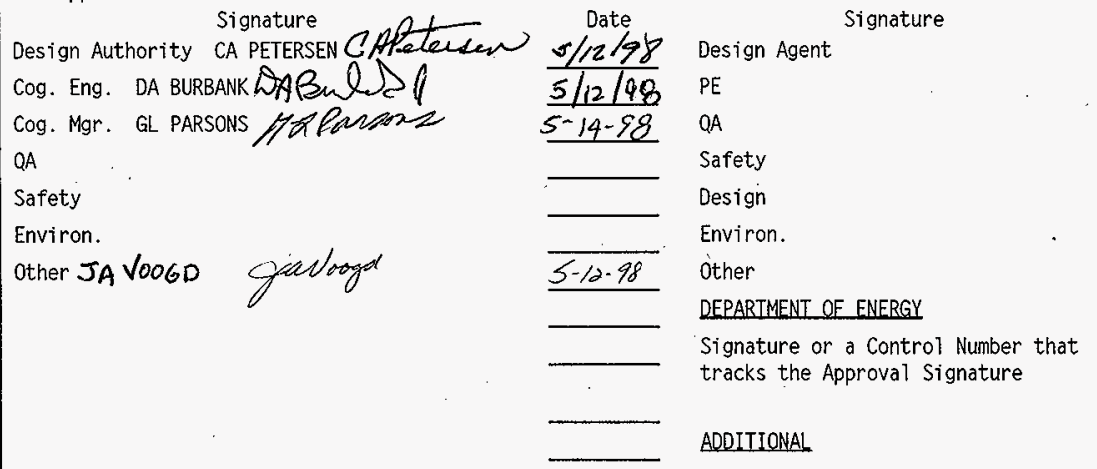




\title{
Design Requirements Document for Project W-465, Immobilized Low-Activity Waste Interim Storage
}

\author{
D.A. BURBANK
}

COGEMA Engineering Corporation, Richland, WA 99352

U.S. Department of Energy Contract DE-AC06-96RL-13200

EDT/ECN: 165856

Org Code: 51400

UC: 721

B\&R Code: EW3130010

Charge Code: $D 4 D K G$

Total Pages: -61 ga 62

Key Words: ILAW, Storage, Grout Vault, TWRS

Abstract: The ILAW Interim Storage subproject wi11 provide storage capacity for immobilized low-activity waste product sold to DOE by the privatization contractor. This document identifies the design requirements that the project shall comply with.

TRADEMARK DISCLAIMER: Reference herein to any specific comercial product, process, or service by trade name, trademark, manufacturer, or otherwise, does not necessarily constitute or imply its endorsement, recommendation, or favoring by the United States Goverinment or any agency thereof or its contractors or subcontractors.

Printed in the United States of America. To obtain copies of this document, contact: WHC/BCS Document Control Services, P.O. Box 1970, Mailstop H6-08, Richland WA 99352, Phone (509) 372-2420; Fax (509) 376-4989.

Selease Approval 4 ardal 5-19-98

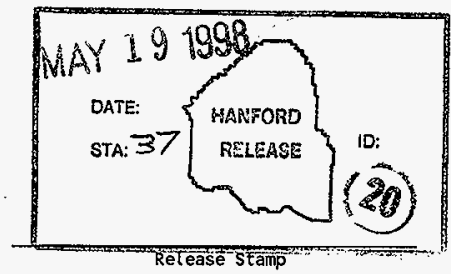


(2) Title

Design Requirements Document for Project W-465, Immobilized Low-Activity Waste Interim Storage

CHANGE CONTROL RECORO

\begin{tabular}{|c|c|c|}
\hline (3) & Revision & (4) Description of Change - Replace, Add, and Delete Pages \\
\hline & 0 & (7) EDT 617642, dated January 27, 1997 \\
\hline & RS & $\begin{array}{l}\text { General revision to reflect findings and } \\
\text { comments received during conceptual design. } \\
\text { Revised Figure 1-1 to reflect new HSTD } \\
\text { structure. Added DOT specs to Table } 2-2 \text {. } \\
\text { Replaced Figure } 3-1 \text { with depiction of new } \\
\text { design concept. Deleted section } 3.2 .4 .1 \text {. } \\
\text { Revised section } 3.3 .1 .3 .2 \text {. Added section } \\
3.3 .1 .3 .24 \text {. Per ECN-165856 }\end{array}$ \\
\hline
\end{tabular}

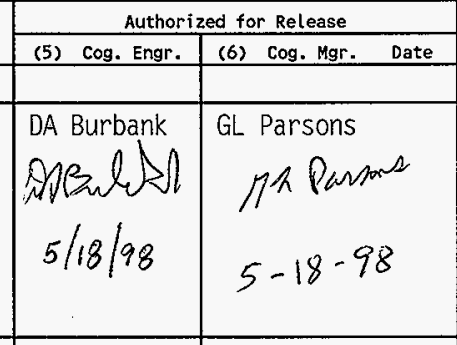




\section{DESIGN REQUIREMENTS DOCUMENT FOR PROJECT W-465, IMMOBILIZED LOW-ACTIVITY WASTE INTERIM STORAGE}

May 1998

D. A. Burbank

COGEMA Engineering Corporation

Richland, Washington 


\section{HNF-SD-W465-DRD-001 \\ Revision 1}

\section{CONTENTS}

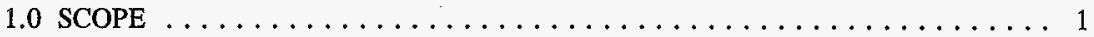

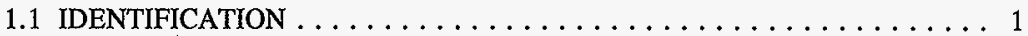

1.2 SYSTEM OVERVIEW $\ldots \ldots \ldots \ldots \ldots \ldots \ldots \ldots \ldots \ldots \ldots$

1.2.1 Tank Waste Remediation System Environmental Impact Statement . . . . 2

1.2.2 Tri-Party Agreement Milestones . . . . . . . . . . . . . 5

2.0 APPLICABLE DOCUMENTS $\ldots \ldots \ldots \ldots \ldots \ldots \ldots \ldots \ldots$

2.1 GOVERNMENT DOCUMENTS $\ldots \ldots \ldots \ldots \ldots \ldots \ldots \ldots \ldots$

2.2 NON-GOVERNMENT DOCUMENTS $\ldots \ldots \ldots \ldots \ldots \ldots \ldots \ldots \ldots$

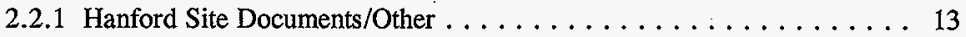

2.2.2 Information Documents $\ldots \ldots \ldots \ldots \ldots \ldots \ldots \ldots \ldots$

3.0 PROJECT FUNCTIONS AND REQUIREMENTS $\ldots \ldots \ldots \ldots \ldots \ldots \ldots \ldots$

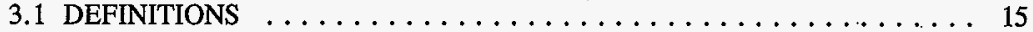

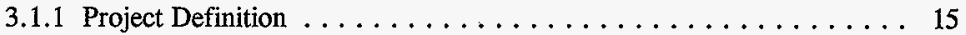

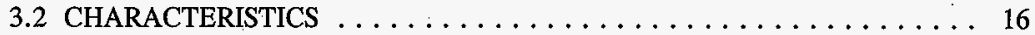

3.2.1 Storage Function Performance Characteristics $\ldots \ldots \ldots \ldots \ldots 16$

3.2.2 Transport Function Performance Characteristics . . . . . . . . 20

3.2.3 External Interface Requirements $\ldots \ldots \ldots \ldots \ldots \ldots \ldots \ldots \ldots$

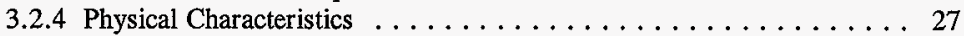

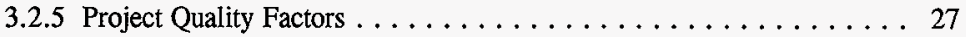

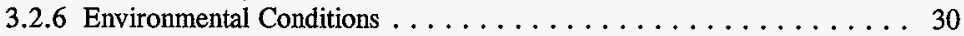

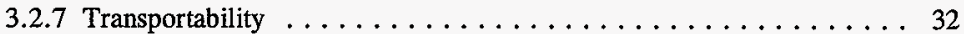

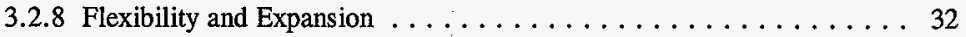

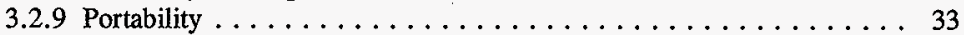

3.3 DESIGN AND CONSTRUCTION $\ldots \ldots \ldots \ldots \ldots \ldots \ldots \ldots \ldots \ldots$

3.3.1 Materials (i.e., Structure, Shielding) $\ldots \ldots \ldots \ldots \ldots \ldots \ldots \ldots$

3.3.2 Electromagnetic Radiation . . . . . . . . . . . . . . 41

3.3.3 Nameplates and Product Marking . . . . . . . . . . . . . 41

3.3 .4 Workmanship . . . . . . . . . . . . . . . . . . 41

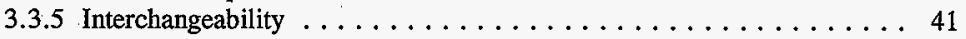

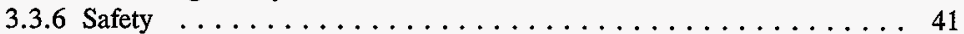

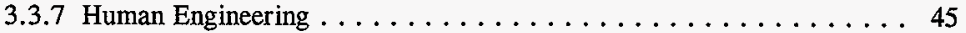

3.3 .8 Nuclear Control $\ldots \ldots \ldots \ldots \ldots \ldots \ldots \ldots \ldots \ldots \ldots \ldots$

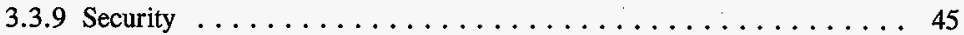

3.3.10 Government Furnished Property Usage . . . . . . . . . . . . . . 45

3.3.11 Computer Resource Reserve Capacity . . . . . . . . . . 45

3.4 INFORMATION AND PROJECT DOCUMENTATION . . . . . . . 46

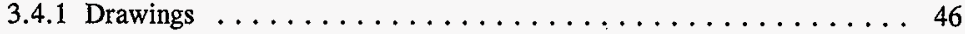

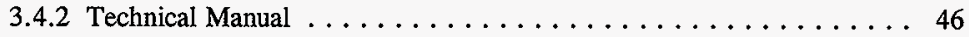

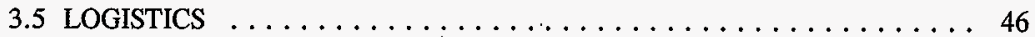


HNF-SD-W465-DRD-001

Revision 1

3.6 PERSONNEL AND TRAINING $\ldots \ldots \ldots \ldots \ldots \ldots \ldots \ldots$

3.7 CHARACTERISTICS AT SUBORDINATE ELEMENTS $\ldots \ldots \ldots \ldots \ldots 46$

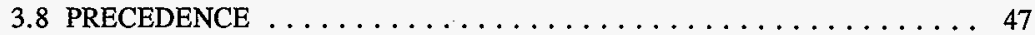

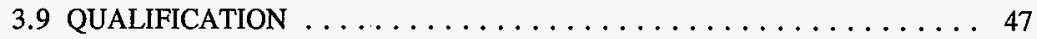

3.10 STANDARD SAMPLE $\ldots \ldots \ldots \ldots \ldots \ldots \ldots \ldots \ldots \ldots$

3.11 PREPRODUCTION SAMPLE, PERIODIC PRODUCTION SAMPLE, PILOT OR PILOT LOT $\ldots \ldots \ldots \ldots \ldots \ldots \ldots \ldots \ldots \ldots \ldots$

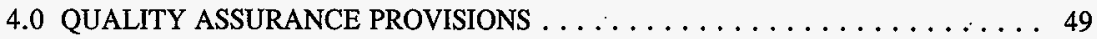

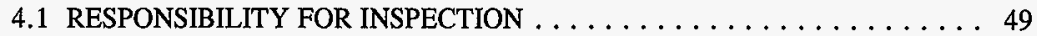

4.2 SPECIAL TESTS AND EXAMINATIONS $\ldots \ldots \ldots \ldots \ldots \ldots \ldots$

4.3 REQUIREMENTS CROSS REFERENCE $\ldots \ldots \ldots \ldots \ldots \ldots \ldots \ldots \ldots$

5.0 PREPARATION FOR DELIVERY $\ldots \ldots \ldots \ldots \ldots \ldots \ldots \ldots \ldots \ldots$

6.0 NOTES AND REFERENCES $\ldots \ldots \ldots \ldots \ldots \ldots \ldots \ldots \ldots \ldots \ldots \ldots \ldots$

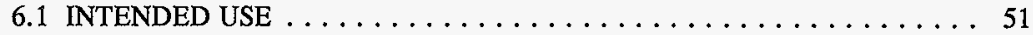

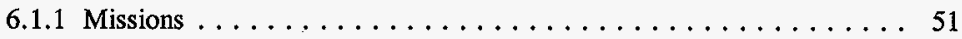

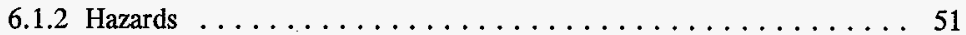

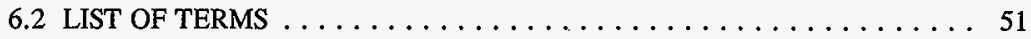

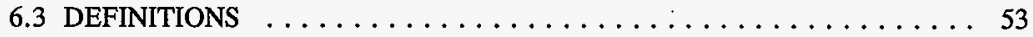

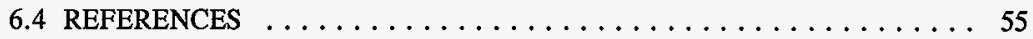




\section{HNF-SD-W465-DRD-001}

Revision 1

\section{LIST OF FIGURES}

1-1. Immobilized Low-Activity Waste Interim Storage

Systems Engineering Functional Hierarchy . . . . . . . . . . . . 7

3-1. Immobilized Low-Activity Waste Storage Concept. . . . . . . . . . . . . . . 17

3-2. External Interfaces. . . . . . . . . . . . . . . . . . . 21

\section{LIST OF TABLES}

1-1. Phased Implementation Alternative. . . . . . . . . . . . . . . 3

1-2. Selected Tri-Party Agreement Milestones. . . . . . . . . . . . . . . . 6

2-1. Applicable Constraint Documents . . . . . . . . . . . . . . . . 9

2-2. Company-Wide Controlled Manuals and Other Applicable Codes. . . . . . . . 11

2-3. Information Documents. . . . . . . . . . . . . . . . . . . . . . 13

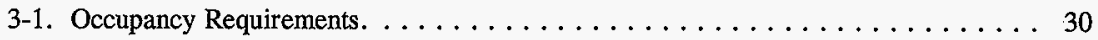

3-2. Storage Facility Shield Design Criteria. . . . . . . . . . . . . . . . . 34

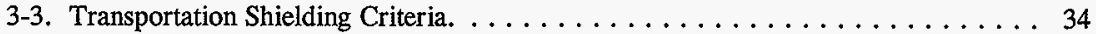

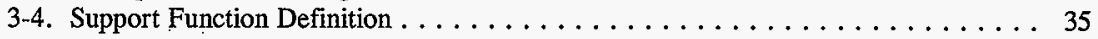

3-5. Ventilation Zones. . . . . . . . . . . . . . . . . . . . . . 44 
HNF-SD-W465-DRD-001

Revision 1

DESIGN REQUIREMENTS DOCUMENT FOR PROJECT W-465, IMMOBILIZED LOW-ACTIVITY WASTE INTERIM STORAGE

\subsection{SCOPE}

The scope of this Design Requirements Document (DRD) is to identify the functions and associated requirements that must be performed to accept, transport, handle, and store immobilized low-activity waste (ILAW) produced by the privatized Tank Waste Remediation System (TWRS) treatment contractors. The functional and performance requirements in this document provide the basis for the conceptual design of the TWRS ILAW Interim Storage facility project and provides traceability from the program level requirements to the project design activity. Technical and programmatic risks associated with the TWRS planning basis are discussed in the Tank Waste Remediation System Decisions and Risk Assessment (Johnson 1994).

The design requirements provided in this document will be augmented by additional detailed design data documented by the project.

\subsection{IDENTIFICATION}

Program: TWRS

Project: TWRS ILAW INTERIM STORAGE (Project W-465)

U.S. Department of Energy (DOE) Line Item 00L-EEW-465

Mission: - The mission of the ILAW Interim Storage project is to provide waste acceptance, storage, and transportation services for ILAW product produced by the privatized TWRS treatment contractors.

Type: Non-vital, non-critical facility

\subsection{SYSTEM OVERVIEW}

The Hanford Mission Plan, Volume 1, Site Guidance (DOE 1994) states "The Hanford mission is to clean up the Hanford Site, provide scientific and technological excellence to meet global needs, and to partner in the economic diversification of the region." As part of the Hanford Site mission, the TWRS program identifies the need to store, treat, immobilize, and dispose of the highly radioactive Hanford Site tank wastes and encapsulated cesium and strontium materials in an environmentally sound, safe, and cost effective manner. 
HNF-SD-W465-DRD-001

Revision 1

\subsubsection{Tank Waste Remediation System Environmental Impact Statement}

The TWRS Environmental Impact Statement (EIS) (DOE 1996) describes several alternatives for treating and disposing of the tank waste. The Phased Implementation Alternative is identified as the preferred alternative. Key features of the Phased Implementation Alternative are presented in Table 1-1.

The Phased Implementation alternative includes remediating the tank waste in two phases. The first phase would be a demonstration of the separations and immobilization processes for selected tank waste. The second phase would involve scaling-up the demonstration processes and constructing larger treatment facilities to remediate the remaining tank waste.

This two-phased implementation approach could be applied to any of the tank waste alternatives involving ex situ waste treatment. However, for the purposes of analysis, the processes and activities described for the Ex Situ Intermediate Separations alternative, with some additional separations, was selected as the basis for developing the Phased Implementation alternative. This basis included vitrified glass cullet as a LAW form and vitrified borosilicate glass as a high-level waste (HLW) form. Other types of glass or wastes forms could be selected for HLW or LAW treatment; however, they would have to meet the repository acceptance criteria or performance assessment criteria. The Phased Implementation alternative is presented in two parts; Phase 1 first, then Phase 2.

This alternative also could be implemented by decommissioning the two demonstrationscale facilities after the demonstration phase and constructing and operating two larger size facilities. The environmental impacts of each approach would be approximately the same.

1.2.1.1 Phase 1. During Phase 1, readily retrievable and well-characterized DST waste would be retrieved and processed in two separate demonstration facilities. The waste processed during Phase 1 could also include selected SST waste. One of the facilities would process liquid waste to produce immobilized LAW, while the other facility would produce immobilized LAW and vitrified HLW. The facility for both LAW and HLW immobilization could be constructed as separate facilities. Information used in describing this alternative was developed by the TWRS EIS contractor (Jacobs 1995).

The immobilized LAW would be sealed in containers at the treatment facilities and then transported to an interim onsite storage facility where it would be stored for disposal during Phase 2. The vitrified HLW would be placed in canisters and transported to an interim onsite storage facility, where it would be stored awaiting shipment and disposal at the potential geologic repository. 
HNF-SD-W465-DRD-001

Revision 1

Table 1-1. Phased Implementation Alternative.

Phased implementation

(Phase 1: 1997 to 2012)

(Phase 2: 2004 to 2040)

Preferred Alternative

\section{Phase 1:}

Construct two low-activity waste separations and immobilization demonstration facilities (one facility would include high-level waste vitrification).

Operate facilities for up to 10 years and treat up to approximately $76 \mathrm{ML}$ (20 Mgal) of the tank waste volume.

Store treated waste onsite in the Canister Storage Building pending development of an onsite disposal facility and availability of a geologic repository.

\section{Phase 2:}

Construct two combined low-activity waste separations and immobilization facilities and one high-level waste vitrification facility.

Retrieve all waste practicable (assumed to be 99 percent) from all single- and double-shell tanks.

Separate tank waste into high-level and low-activity waste streams (use sludge washing, caustic leaching, ion exchange, and other separations as required).

Store high-level waste onsite for up to 50 years pending availability of a geologic repository.

Dispose of high-level waste offsite at a geologic repository.

Dispose of low-activity waste onsite in near-surface vaults.

During Phase 1, canisters of vitrified HLW and canisters of separated radionuclides would be placed into shipping casks and transported to the onsite Canister Storage Building for interim storage. Each canister would be placed into a storage tube in one of the Canister Storage Building vaults. The Canister Storage Building is located in the 200 East Area and was constructed as an interim storage facility. The NEPA analysis for construction of the 


\section{HNF-SD-W465-DRD-001 \\ Revision 1}

Canister Storage Building was performed under the K Basins Spent Nuclear Fuel EIS (DOE 1995).

The Phase 1 immobilized LAW would be placed into disposal containers and transported to the existing grout vaults for interim storage until the permanent onsite disposal vaults were constructed during Phase 2. The NEPA analysis for the construction of the grout vaults was previously performed in the Hanford Defense Waste EIS (DOE 1987). The LAW placed in interim storage during Phase 1 would be retrieved and transported to the LAW disposal vaults during Phase 2.

Each of the LAW treatment facilities would operate for a 10 -year period. The HLW treatment facility would operate for a 6-year period, which could be extended to a 10-year period.

The following operations would be implemented under Phase 1.

- Retrieve selected liquid waste for LAW processing.

- Retrieve selected DST and SST waste for HLW processing.

- Transfer liquid waste to receiver tanks.

- Transfer selected waste for HLW processing directly to the HLW facility.

- Perform separations to remove cesium, technetium, strontium, transuranic elements, and sludge from the LAW stream.

- Store separated cesium and technetium at the treatment facilities or package and transport to the Canister Storage Building for onsite interim storage pending future HLW waste treatment.

- Return the sludge, strontium, and transuranic waste separated before LAW processing to DSTs for storage.

- Immobilize the LAW and vitrify the HLW.

- Place the vitrified HLW into canisters.

- Place the immobilized LAW into containers.

- Transport the immobilized waste to onsite interim storage facilities.

1.2.1.2 Phase 2. Phase 2 would be implemented to complete the remediation of the tank waste following successful implementation of Phase 1. Implementation of Phase 2 would 


\section{HNF-SD-W465-DRD-001}

\section{Revision 1}

involve the continued operation of Phase 1 facilities plus construction of two full-scale separations and LAW vitrification facilities and a full-scale HLW vitrification facility. Phase 2 would include the retrieval and treatment of the remaining DST and SST waste as well as the waste contained in the miscellaneous underground storage tanks (MUSTs). As much of the tank waste as practicable (assumed to be 99 percent) would be recovered from each tank. The recovered waste stream then would be transferred to one of the treatment facilities where it would be separated into HLW and LAW waste streams for immobilization.

. The HLW stream would be vitrified, placed into canisters and then placed into Hanford Multi-Purpose Canisters for interim storage and disposal at the potential geologic repository. The LAW would be immobilized and placed into sealed containers similar to those used in Phase 1. The immobilized LAW would be placed into near-surface retrievable disposal vaults.

For purposes of analysis and in order to present a complete and representative alternative, the complete Phased Implementation alternative would include the following components:

- Completion of the waste retrieval and transfer system as described for the Ex Situ Intermediate Separations alternative

- Construction and operation of the ex situ treatment facilities, similar to those described for the Ex Situ Intermediate Separations alternative, to provide the treatment capacity required to complete tank waste remediation

- Construction and operation of interim HLW storage and LAW disposal vaults of the same size and type as described for the Ex Situ Intermediate Separations alternative to provide for interim HLW storage and LAW disposal.

\subsubsection{Tri-Party Agreement Milestones}

The sixth amendment to the Hanford Federal Facility Agreement and Consent Order (Tri-Party Agreement) (Ecology et al. 1996) and DOE policy decision form the bases for the TWRS mission. The bases include: (1) retrieval of both single-shell and double-shell tank waste, (2) separation of high-level (disposed offsite) and low-level fractions (stored and disposed onsite), and (3) intermediate separations. Change Order M-90-96-01 to the Tri-Party Agreement specifies milestones for ILAW interim storage as shown in Table 1-2. 
HNF-SD-W465-DRD-001

Revision 1

Table 1-2. Selected Tri-Party Agreement Milestones.

\begin{tabular}{|l|l|c|}
\hline $\begin{array}{c}\text { Milestone } \\
\text { number }\end{array}$ & \multicolumn{1}{|c|}{ Title } & Date \\
\hline M-90-00 & $\begin{array}{l}\text { Complete acquisition of new facilities, modification of } \\
\text { existing facilities, and/or modification of planned facilities } \\
\text { as necessary for storage of Hanford site IHLW and } \\
\text { ILAW, and disposal of ILAW. }\end{array}$ & $\begin{array}{c}\text { Six months } \\
\text { after approval } \\
\text { of PMP }\end{array}$ \\
\hline M-90-01 & $\begin{array}{l}\text { Submit interim storage and disposal ILAW, and interim } \\
\text { storage IHLW Project Management Plans (PMP) to } \\
\text { Ecology pursuant to Agreement section 11.5. }\end{array}$ & $\begin{array}{c}\text { December } \\
1997\end{array}$ \\
\hline M-90-02T & $\begin{array}{l}\text { Complete ILAW interim storage facility conceptual } \\
\text { design. }\end{array}$ & June 1998 \\
\hline M-90-03 & Initiate ILAW interim storage facility construction. & June 2001 \\
\hline M-90-04T & Complete ILAW interim storage facility detailed design. & June 2001 \\
\hline M-90-06 & Initiate hot operations of ILAW interim storage facility. & $\begin{array}{c}\text { December } \\
2002\end{array}$ \\
\hline
\end{tabular}

IHLW = Immobilized High-Level Waste.

ILAW $=$ Immobilized Low-Activity Waste

PMP $=$ Project Management Plans.

A systems engineering process is being applied at the Hanford Site and is being implemented by the TWRS to establish the functions and requirements necessary for accomplishing the TWRS mission. The initial TWRS technical baseline has been established through four levels of functional decomposition and documented in the Tank Waste Remediation System Functions and Requirements (WHC 1996). The Program requirements to implement the Systems Engineering at the Hanford Site are defined in Fiscal Year 1995 Hanford Mission Plan (DOE 1994a). The policy and guidance for application of systems engineering throughout the TWRS Program is described in the Tank Waste Remediation System (TWRS) Systems Engineering Management Plan (DOE 1994, Annex 2).

The development of the functions that form the basis for the ILAW Storage Project has been provided through continuation of the systems engineering process from the top-level system requirements. Figure 1-1 shows the TWRS functional hierarchy pertinent to this project. 


\section{HNF-SD-W465-DRD-001 \\ Revision 1}

Figure 1-1. Immobilized Low-Activity Waste Interim Storage Systems Engineering Functional Hierarchy.
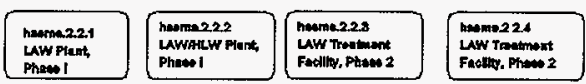

hwama.2.50

IHLW swhat

Modulas Phese 1

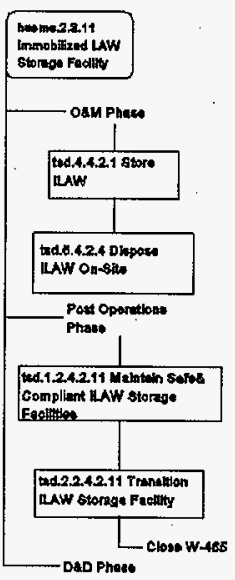

thanme232

Domble and Tenk

Gyatem

\section{heme 245.}

Iranobitired LAW

Dhpoes Fadility

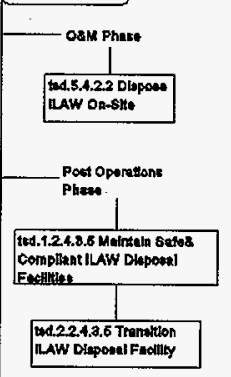

Deo Phate 


\section{HNF-SD-W465-DRD-001}

\section{Revision 1}

This page intentionally left blank. 


\subsection{APPLICABLE DOCUMENTS}

The documents provided in the following tables form a part of this specification to the extent specified. In the event of conflict between the documents referenced in the tables and the contents of this specification, the contents of this specification shall be considered a superseding requirement.

\subsection{GOVERNMENT DOCUMENTS}

Federal government and Washington State regulations along with DOE orders have been reviewed to determine constraints applicable to the design, construction, and operation of the ILAW Storage to the extent specified. To the extent specified, the references listed in Table 2-1 represent requirements imposed on the ILAW Storage Project by sources external to the TWRS program.

Table 2-1. Applicable Constraint Documents. (3 Sheets)

\begin{tabular}{|l|l|}
\hline \multicolumn{1}{|c|}{ Document Identifier } & \multicolumn{1}{|c|}{ Title } \\
\hline 10 CFR 61 & Licensing Requirements for Land Disposal of Radioactive Waste \\
\hline 10 CFR 830 & $\begin{array}{l}\text { Nuclear Safety Management, Subpart A, General Provisions, Section 830.120, } \\
\text { Quality Assurance Requirements }\end{array}$ \\
\hline 10 CFR 835 & Occupational Radiation Protection \\
\hline 29 CFR 1910 & Occupational Safety and Health Standards \\
\hline 29 CFR 1926 & Safety and Health Regulations for Construction \\
\hline 40 CFR 50 & EPA Regulations on National Primary and Secondary Air Quality Standards \\
\hline 40 CFR 52 & Approval and Promulgation of Implementation Plans \\
\hline 40 CFR 61 & National Emission Standards for Hazardous Air Pollutants \\
\hline 40 CFR 262 & Standards Applicable to Generators of Hazardous Waste \\
\hline 40 CFR 264 & $\begin{array}{l}\text { Standards for Owners and Operators of Hazardous Waste Treatment, Storage, and } \\
\text { Disposal Facilities }\end{array}$ \\
\hline 40 CFR 270 & EPA Administered Permit Programs: The Hazardous Waste Permit Program \\
\hline 49 CFR 172 & Hazardous Materials Designations \\
\hline 49 CFR 173 & Hazardous Materials Packaging Requirements \\
\hline Bernero 1993 & Bernero, NRC letter dated March 2, 1993 \\
\hline DOE Order 430.1 & Life-Cycle Asset Management \\
\hline DOE Order 460.1 & Packaging and Transportation Safety \\
\hline DOE Order 460.2 & Departmental Materiais Transportation and Packaging Management \\
\hline
\end{tabular}


Table 2-1. Applicable Constraint Documents. (3 Sheets)

\begin{tabular}{|c|c|}
\hline Document Identifier & Title \\
\hline DOE Order 4330.4B & Maintenance Management Program. \\
\hline DOE Order 1540.2 & Hazardous Material Packaging for Transportation - Administrative Procedures \\
\hline DOE Order 5400.1 & General Environmental Protection Program \\
\hline DOE Order $5400.5(1993)$ & Radiation Protection of the Public and the Environment \\
\hline DOE Order 5480.3 & $\begin{array}{l}\text { Safety Requirements for the Packaging and Transportation of Hazardous } \\
\text { Materials, Hazardous Substances, and Hazardous Waste }\end{array}$ \\
\hline DOE Order $5480.4(1993)$ & Environmental Protection, Safety, and Health Protection Standards \\
\hline DOE Order 5480.7A (1993) & Fire Protection \\
\hline RL ID 5480.7 (1994) & Fire Protection \\
\hline DOE Order 5480.10 & Contractor Industrial Hygiene Program \\
\hline DOE Order 5480.11 (1988) & Radiation Protection for Occupational Workers \\
\hline DOE Order 5480.19 & Conduct of Operations Requirements for DOE Facilities \\
\hline $\begin{array}{l}\text { DOE Order } 5480.20 \mathrm{~A} \\
(1994)\end{array}$ & $\begin{array}{l}\text { Personnel Selection, Qualification, Training, and Staffing Requirements at DOE } \\
\text { Reactor and Non-Reactor Nuclear Facilities }\end{array}$ \\
\hline DOE Order 5480.21 & Unreviewed Safety Questions \\
\hline DOE Order 5480.22 & Technical Safety Requirements \\
\hline DOE Order 5480.23 & Nuclear Safety Anaiysis Reports \\
\hline DOE Order 5480.28 & Natural Phenomena Hazards Mitigation \\
\hline DOE Order 5483.1A (1983) & $\begin{array}{l}\text { Occupational Safety and Health Program for DOB Contractor Employees at } \\
\text { Government-Owned Contractor-Operated Facilities }\end{array}$ \\
\hline DOE Order $5500.7 \mathrm{~B}$ & Emergency Operations Records Protection Program \\
\hline DOE Order $5700.6 \mathrm{C}$ & Quality Assurance \\
\hline DOE Order $5820.2 \mathrm{~A}$ & Radioactive Waste Management \\
\hline DOE Order 6430.1A (1989) & General Design Criteria \\
\hline NFPA $70(1996)$ & National Electrical Code \\
\hline NFPA $101(1994)$ & Code for Safety of Life from Fire in Buildings and Structures \\
\hline UBC (1994) & Uniform Building Code \\
\hline Tri-Party Agreement (1996) & Hanford Federal Facility Agreement and Consent Order (Amendment 6) \\
\hline WAC $173-400$ & General Air Regulations \\
\hline WAC 173-401 & Operating Permit Regulation \\
\hline WAC 173.460 & Toxic Air Pollutants \\
\hline
\end{tabular}


HNF-SD-W465-DRD-001

Revision 1

Table 2-1. Applicable Constraint Documents. (3 Sheets)

\begin{tabular}{|l|l|}
\hline \multicolumn{1}{|c|}{ Document Identifier } & \multicolumn{1}{c|}{ Title } \\
\hline WAC 173-480 & Ambient Air Quality Standards and Emission Limits for Radionuclides \\
\hline WAC 173-303 & Dangerous Waste Regulations \\
\hline WAC 246-220 & Radiation Protection--General Provisions \\
\hline WAC 246-247 & Radiation Protection - Air Emissions \\
\hline WAS 246-272 & On-Site Sewage Systems \\
\hline WAC 246-290 & Public Water Supplies \\
\hline
\end{tabular}

CFR $=$ Code of Federal Regulations

$\mathrm{EPA}=$ U.S. Environmental Protection Agency

NFPA = National Fire Protection Association

NRC $=$ U.S. Nuclear Regulatory Agency

UBC $=$ Uniform Building Code

WAC $=$ Washington Administrative Code.

\subsection{NON-GOVERNMENT DOCUMENTS}

Table 2-2 provides a list of non-government documents that contain requirements applicable to the ILAW Storage.

Table 2-2. Company-Wide Controlled Manuals and Other Applicable Codes. (2 Sheets)

\begin{tabular}{|c|c|}
\hline Document identifier & Title \\
\hline ASME & $\begin{array}{l}\text { Boiler and Pressure Vessel Code, Section VIII, American Society of } \\
\text { Mechanical Engineers }\end{array}$ \\
\hline ANSU/ISA (1985) & Graphic Symbols for Process Displays \\
\hline ANSI/ISA (1991) & Instrument Loop Diagrams \\
\hline ANSU/ISA (1992) (R) & Binary Logic Diagrams for Process Operations \\
\hline ANSL/ISA (1994) & Instrumentation Symbols and Identification \\
\hline ANSI/ASME B30.2 & Overhead and Gantry Cranes \\
\hline ANSI B30.17 & Overhead and Gantry Cranes \\
\hline ANSI 14.5 & $\begin{array}{l}\text { American National Standards for Radioactive Materials-Leakage Tests on } \\
\text { Packages for Shipment }\end{array}$ \\
\hline HSRCM-1 (DOE/RL-96-109) & Hanford Site Radiological Control Manual \\
\hline NFPA 70 (1996) & National Electrical Code \\
\hline NFPA 101 (1994) & Code for Safety of Life from Fire in Buildings and Structures \\
\hline UBC (1994) & Uniform Building Code \\
\hline
\end{tabular}


HNF-SD-W465-DRD-001

Revision 1

Table 2-2. Company-Wide Controlled Manuals and Other Applicable Codes. (2 Sheets)

\begin{tabular}{|c|c|}
\hline Document identifier & Title \\
\hline WHC-CM-1-3 & Management Requirements and Procedures \\
\hline WHC-CM-1-10 & Safety Manual \\
\hline WHC-CM-1-11 & Industrial Hygiene \\
\hline WHC-CM-2-14 & Hazardous Material Packaging and Shipping \\
\hline WHC-CM-4-2 & Quality Assurance Manual \\
\hline WHC-CM-4-27 & Radiological Control Practices and Procedures. \\
\hline WHC-CM-4-40 & Industrial Hygiene Manual \\
\hline WHC-CM-4-41 & Fire Protection Program Manual \\
\hline WHC-CM-4-46 & Safety Analysis Manual \\
\hline WHC-CM-6-1 & Standard Engineering Practices \\
\hline WHC-CM-6-2 & Project Management \\
\hline WHC-CM-7-5 & Environmental Compliance \\
\hline WHC-EP-0063-4 (1993) & Hanford Site Solid Waste Acceptance Criteria \\
\hline $\begin{array}{l}\text { WSDOT Specs for Roads } \\
2.01 \\
2.03 \\
2.04 \\
2.06 \\
2.07 \\
2.09 \\
4.02 \\
4.04 \\
5.04 \\
7.02 \\
8.01 \\
8.11 \\
8.20 \\
8.21 \\
8.22 \\
\end{array}$ & $\begin{array}{l}\text { Clearing and Grubbing and Roadside Cleanup } \\
\text { Roadway Excavation and Embankment } \\
\text { Haul } \\
\text { Subgrade Preparation } \\
\text { Watering } \\
\text { Structural Excavation } \\
\text { Gravel Bases } \\
\text { Ballast and Crushed Surfacing } \\
\text { Asphalt Concrete Pavement } \\
\text { Culverts } \\
\text { Erosion Control } \\
\text { Guardrail } \\
\text { Illumination, Traffic Signals and Electrical } \\
\text { Permanent Signing } \\
\text { Pavement Markings }\end{array}$ \\
\hline WSDOT M 21-01 & Standard Plans for Road, Bridge and Municipal Construction \\
\hline WSDOT M $41-10$ & Standard Specifications for Roads, Bridge and Municipal Construction \\
\hline WSDOT M 22-01 & Design Manual \\
\hline WSDOT M 41-01 & Construction Manual \\
\hline WSDOT M41-10 & Road, Bridge, and Municipal Construction \\
\hline WSDOT M 46-01 & Materials Branch Laboratory Manual \\
\hline
\end{tabular}




\section{Revision 1}

Table 2-2. Company-Wide Controlled Manuals and Other Applicable Codes. (2 Sheets)

\begin{tabular}{|c|l|}
\hline Document identifier & \multicolumn{1}{|c|}{ Title } \\
\hline WHC-SD-ETF-WAC-001 (1994) & $\begin{array}{l}\text { Acceptance of Feed Streams for Storage and Treatment at the LERF/ETF } \\
\text { Complex }\end{array}$ \\
\hline
\end{tabular}
ANSI = American National Standards Institute
ASHRAE = American Society of Heating, Refrigeration, and Air Conditioning Engineers
ASME $=$ American Society of Mechanical Engineers
$\mathrm{ETF}=$ Effluent Treatment Facility
HSRCM = Hanford Site Radiological Control Manual
ISA = Instrument Society of America
LERF = Liquid Effluent Retention Facility.

\subsubsection{Hanford Site Documents/Other}

Selected DOE orders and federal government and Washington State regulations have been reviewed by the Project Hanford Management Contractor (PHMC) to provide a consistent interpretation of the constraints for application at the Hanford Site. These constraints are represented in company-wide Controlled Manuals (CM).

\subsubsection{Information Documents}

Table 2-3 lists other information documents.

Table 2-3. Information Documents.

\begin{tabular}{|l|l|}
\hline \multicolumn{1}{|c|}{ Document identifier } & \multicolumn{1}{c|}{ Title } \\
\hline $\begin{array}{l}\text { WHC-SD-GN-DGS- } \\
30011\end{array}$ & Radiological Design Guide \\
\hline KH-SD-GN-DGS-30012 & HPS, Architectural/Civil Manual \\
\hline KH-SD-GN-DGS-30013 & HPS, Electrical Manual \\
\hline KH-SD-GN-DGS-30014 & HPS, Instrumentation Manual \\
\hline KH-SD-GN-DGS-30015 & HPS, Mechanical Manual \\
\hline WHC-IP-1043 & $\begin{array}{l}\text { Westinghouse Hanford Company Occupational } \\
\text { ALARA Program }\end{array}$ \\
\hline DOE/RL-92-36 & Hanford Site Hoisting and Rigging Manual \\
\hline CMAA-70 & Electric Overhead Traveling Cranes \\
\hline
\end{tabular}

CMAA $=$ Crane Manufacturer's Association of America 
HNF-SD-W465-DRD-001

Revision 1

This page intentionally left blank. 
HNF-SD-W465-DRD-001

Revision 1

\subsection{PROJECT FUNCTIONS AND REQUIREMENTS}

\subsection{DEFINITIONS}

The functions, requirements, and external interfaces for the ILAW interim storage system are provided in the following sections.

\subsubsection{Project Definition}

The Hanford Site Technical Database, as described in the Tank Waste Remediation System Technical Baseline Summary Description, (Treat, 1998) established the architecture element hsems.2.3.11: Immobilized LAW Storage Facility. The functions assigned to this architecture element are tsd.4.4.2.1: Store ILAW, tsd.1.2.4.2.11: Maintain Safe and Compliant ILAW Storage Facilities, and tsd.2.2.4.2.11: Transition ILAW Storage Facility.

The ILAW Storage Facility will perform these functions by transporting containers loaded with ILAW packages (provided by the immobilization vendors) from the LLW Immobilization Facility, placing the waste packages in their designated storage locations, monitoring the packages for storage containment integrity, and if necessary, eventually retrieving the packages from storage to prepare them for onsite disposal. The ILAW Storage Facility furnishes shipping containers to the LLW Immobilization Facility. The LLW Immobilization Facility loads the shipping containers with packages of ILAW. The ILAW Storage facility collects the loaded shipping containers and transports them to the interim storage area as required.

The ILAW Interim Storage project, W-465, shall provide equipment and facilities for accomplishing the Store ILAW function. The scope of the ILAW Storage Project includes the design and construction of a facility to provide storage space for ILAW packages, design and procurement of transport vehicles and shielded shipping containers, transportation of loaded and empty shipping containers, shipping and receiving of ILAW packages, loading and unloading of ILAW packages from the transport container, package handling for placement and retrieval of ILAW within the storage area, and monitoring of the stored ILAW packages.

Using systems engineering procedures, the finctions assigned to the ILAW Storage Facility have been further decomposed into subordinate functions essential for the performance of the system:

\section{Transport Functions:}

Provide Shipping Containers. The project shall provide shielded shipping containers suitable for transporting the ILAW waste packages safely. 


\section{HNF-SD-W465-DRD-001 \\ Revision 1}

Provide Transport Vehicles. The project shall provide transport vehicles suitable for transporting the ILAW waste packages safely.

Transport Empty Shipping Containers. The system shall provide transportation of empty ILAW shipping containers to the vendor.

Transport Loaded Shipping Containers. The system shall provide transportation of loaded ILAW shipping containers from the vendor.

\section{Storage Functions:}

Ship/Receive ILAW. The Interim Storage facility shall have the capability to receive and ship ILAW packages in shipping containers on a transport vehicle.

Handle ILAW. The facility shall be capable of handling ILAW packages for placement and retrieval within the storage area.

Monitor ILAW. The facility shall be capable of monitoring the integrity of the ILAW packages in storage.

Load/Unload ILAW. The facility shall have the capability to load and unload a waste package into and out of the shipping container.

Provide ILAW Storage Space. The facility shall provide space suitable for storing the ILAW packages safely.

\subsection{CHARACTERISTICS}

Characteristics are the specific constraints and expected system performance requirements identified for the ILAW Storage project. Where specific requirements have not been identified for a characteristic, it is noted in the appropriate section that no requirements have been identified. If additional information must be developed to verify or derive a requirement, an issue is identified and a description of the required analysis necessary to resolve the issue is provided.

\subsubsection{Storage Function Performance Characteristics}

This section provides the design criteria for the storage functions of the ILAW storage project. These criteria are based on the strategy identified in the ILAW Interim Storage Alternatives Generation and Analysis (AGA) report (Burbank 1996). A diagram representing a concept for ILAW storage is shown in Figure 3-1. 


\section{HNF-SD-W465-DRD-001 \\ Revision 1}

Figure 3-1. Immobilized Low-Activity Waste Storage Concept.

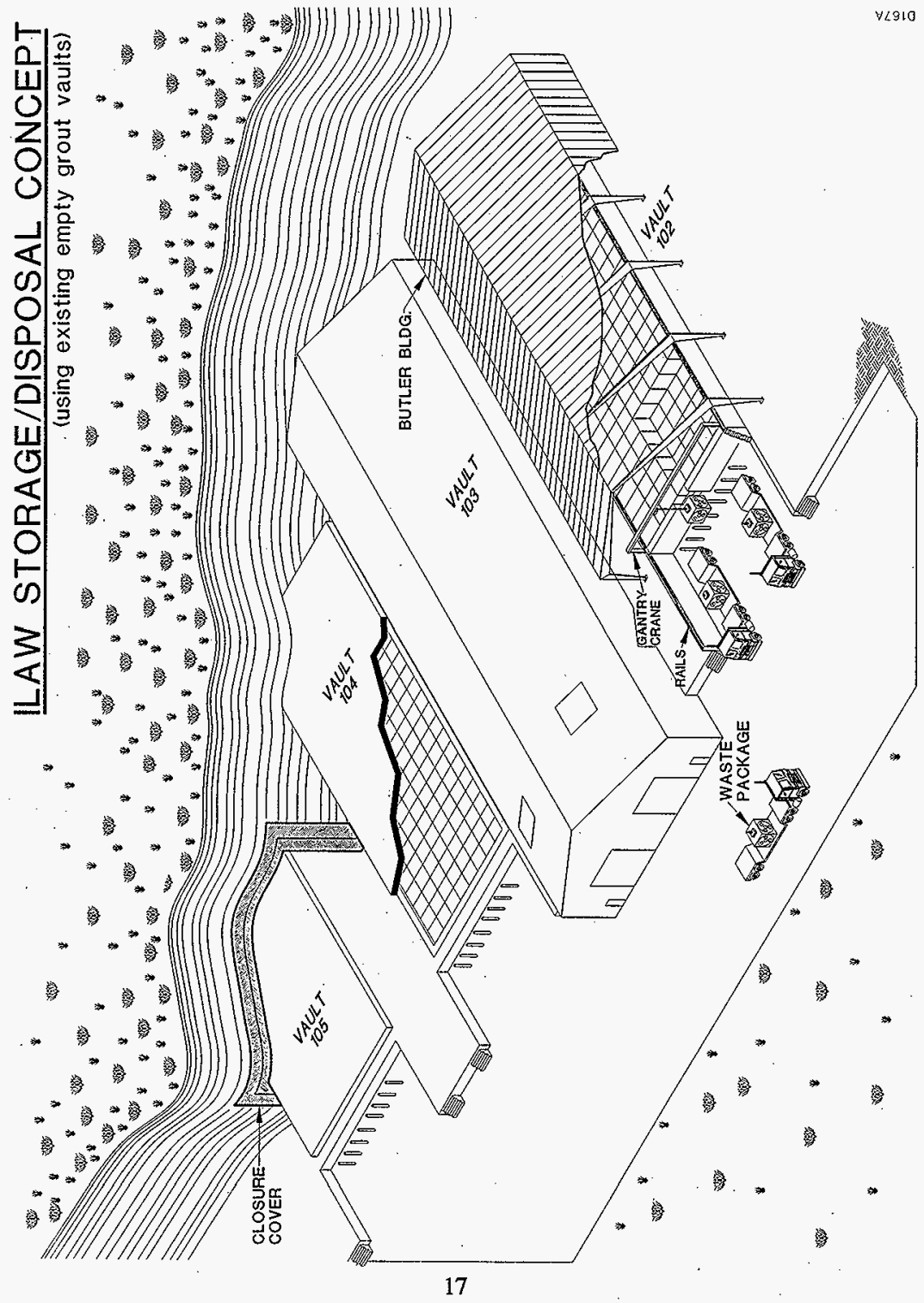




\section{HNF-SD-W465-DRD-001 \\ Revision 1}

3.2.1.1 Shipping and Receiving. The ILAW storage facility shall be capable of receiving no less than 9 full transport containers and shipping no less than 9 empty transport containers per operating day.

Issue: The package count and container throughput is based on the median package description in the privatization Request for Proposals (RFP) and the peak instantaneous production rate, assuming two vendors. See section 3.2.3 for waste package interface descriptions. Package count and throughput will change if the package size differs from the median description.

Required Analysis: Package count and container throughput will be finalized when the details of the private vendor waste package configuration have been agreed to by the vendors, the PHMC contractor, and DOE.

3.2.1.2 Package Handling. The ILAW storage facility shall be capable of handling waste packages for placement and retrieval within the storage area and the shipping/receiving area. Package handling shall be by crane and/or forklift. Package handling equipment shall be remotely operated and/or shielded to minimize operator radiation exposure.

Issue: Details of the waste package configuration are unknown at this time. The private vendors are to develop waste package details during Phase IA of the contract. The ILAW storage project will have to maintain an interface with the waste package design activities.

Required Analysis: The requirements and constraints of the ILAW storage project must be considered during immobilization process development and negotiations with the vendors. Each vendor that ships waste packages to the ILAW storage project should use the same standard waste package.

3.2.1.3 Monitoring and Control. The ILAW facility shall be capable of monitoring and controlling the movement, placement, storage, and retrieval of waste packages into and out of the storage area. Waste package identification and location information shall be maintained in an electronic database. The facility shall be capable of monitoring the condition of packages in storage through visual inspection via closed circuit television. Leak collection and detection systems shall be monitored for the presence of free liquids. Remote handling of waste packages by crane and/or forklift shall be controlled and monitored from a central control room location.

Issue: The regulatory status of the stored ILAW is assumed to be that of a listed Resource Conservation and Recovery Act of 1976 (RCRA) waste. Pending changes in the EPA Hazardous Waste Identification and Listing Rules may allow the ILAW to exit RCRA. 


\section{HNF-SD-W465-DRD-001}

Revision 1

Required Analysis: An formal analysis of the regulatory impacts of the proposed changes on the ILAW storage project is required. The analysis should consider the potential for ILAW to exit RCRA, and the impacts on design, operating, maintenance and monitoring requirements if the ILAW can exit the RCRA system.

3.2.1.4 Loading and Unloading. The ILAW storage facility shall be capable of unloading or loading no less than 9 waste packages per operating day from transport containers.

Issue: Loading and unloading waste packages into and out of the transport container will be a remote operation due to the expected radiation dose rate from the waste package. The configuration of the transport container and the design of the unloading area depends on the operating strategy for this operation.

Required Analysis: Determine the operating strategy for unloading and loading waste packages to and from the transport container. Determine whether or not the transport container is removed from the transport vehicle during this operation.

3.2.1.5 Provide Storage Space. The storage area shall consist of the interior of the four former grout vaults, buildings $218-\mathrm{E}-16-102,-103,-104$, and -105 . The total floor area of each vault is $579.28 \mathrm{~m}^{2}\left(6,236.75 \mathrm{ft}^{2}\right)$. Waste packages shall be stacked no more than six high. Horizontal package spacing shall be not less than $10 \mathrm{~cm}(4 \mathrm{in}$.) for packages placed in a disposal configuration. Packages in a storage configuration have no limits on minimum horizontal spacing.

Issue 1: The ILAW storage AGA report does not specify the means of entry into the vault. Preliminary concepts developed a method for entry through the roof and two methods for entry through the wall. All of the concepts were rated approximately equivalent in the initial analysis.

Required Analysis: More detailed analysis is required to develop and evaluate the different vault entry method concepts.

Issue 2: A final decision on the possible use of the vaults for disposal of ILAW is expected at the end of FY 1997, following the alternatives analysis for ILAW disposal. The assessment of vault disposal options could impact the configuration of the package array and the capacity of the storage system.

Required Analysis: Complete the alternatives analysis for ILAW disposal in FY 1997. Complete the sensitivity cases for vault disposal configurations in the ILAW performance assessment. 


\subsubsection{Transport Function Performance Characteristics}

This section provides the design criteria for the transport functions of the ILAW storage project. These functions provide the transport vehicles and shielded ILAW transport containers. Transportation services shall provide empty transport containers to the private vendors.

Issue: The design details of the interface between the ILAW waste package, the shielded transport container, and the transport vehicle are not known. Design, testing, safety analysis, and certification of the transport container/waste package system will be required once the system has been selected.

3.2.2.1 Provide Shipping Containers. The project shall provide shielded shipping containers suitable for transporting the ILAW waste packages safely. Shielding requirements shall conform to DOT regulations and DOE 5480.11. Shipping containers shall be sized to hold the maximum practical number of waste packages consistent with transport vehicle load limits.

3.2.2.2 Provide Transport Vehicles. The project shall provide transport vehicles suitable for transporting the ILAW waste packages safely. Transportation shall be via site roadways. The maximum gross weight of a fully loaded transport vehicle shall be no more than $45,000 \mathrm{~kg}$.

3.2.2.3 Transport Empty Shipping Containers. The system shall provide transportation of empty ILAW shipping containers from the ILAW storage facility to the vendor during storage operations. During retrieval operations, the system shall provide transportation of empty ILAW shipping containers from the ILAW disposal facility to the storage facility.

3.2.2.4 Transport Loaded Shipping Containers. The system shall provide transportation of loaded ILAW shipping containers from the vendor to the ILAW storage facility during storage operations. The system shall provide transportation of loaded ILAW shipping containers from the ILAW storage facility to the ILAW Disposal facility during retrieval operations.

\subsubsection{External Interface Requirements}

The interfaces to the ILAW Storage consist of programmatic and administrative interfaces, physical interfaces, and functional interfaces. As a modification to an existing facility, ILAW storage must interface with the existing TWRS infrastructure, new and existing facilities and other DOE and privatized projects. External interfaces for ILAW Storage are shown in Figure 3-2. 


\section{ENPUT}

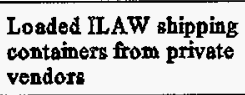

Loaded ILAW shipping containers from private vendore

Product aceeptance information

Infrastructure Support

- Sanitary (potable water)

- Fire waler

- Sanitary sewer

- AC Power

- Telecommunications

Legend

ILAW = Immobilized low-activity waste

\section{OUTPUT}

Empty ILAW shipping containers to private vendors

Loaded ILAW shipping containers to ILAW disposal

Store ILAW

- Ship/receive ILAW

Handle ILAW

- Monitor ILAW

- Load/unload

ILAW

- Provide storage space

\section{Transport IlAW}

- Provide shipping containers

- Provide transport vehicles

- Transport empty

shipping containers

- Transport loaded

shipping containers

IIAW Storage Wastes

- Sanitary sewage

- Solid wastes

- Collected leachate

- Air emissions

Inventory, operations, and monitoring date 


\section{HNF-SD-W465-DRD-001 \\ Revision 1}

The existing vault configuration consists of one vault that has been filled and four empty vaults. Several new projects will be required for waste pretreatment, vitrification and final disposal. With the exception of sludge washing operations, all pretreatment and vitrification functions are slated to become the scope of the private treatment vendor(s).

The primary physical interfaces for ILAW storage are those necessary for: (1) receipt and shipping of the waste packages, (2) transfer of the waste packages to the ILAW storage area, and (3) transfer of shipping containers to interfacing Hanford site programs or to a centralized support facility(s).

3.2.3.1 ILAW Storage Site Location. The ILAW storage facilities shall be located in the former grout vaults, buildings $218-\mathrm{E}-16-102,-103,-104$, and -105 in the 200 East Area. The control and operations buildings shall be adjacent to the storage site.

Basis: Alternatives Generation and Analysis Report for Immobilized Low-Level Waste Interim Storage Architecture (Burbank 1996).

3.2.3.2 ILAW Waste Package. The ILAW waste package is described in the privatization RFP (Wagoner 1995). The details of the package specification that affect the ILAW storage project interface are described below. There are additional requirements on the waste package for the private vendor, however they do not affect the project interfaces or the design requirements of the ILAW storage project.

3.2.3.2.1 Package Description. The ILAW products shall be in the form of a package. The constituent parts of each package are: a sealed metal container enclosing a waste form, in which the ILAW product is emplaced; an optional matrix material, which may be used to encapsulate the waste form; and an optional filler material, which may be used to fill void spaces in the container before it is closed.

3.2.3.2.2 Size and Configuration. The package shall be a rectangular metal container and shall have an external dimension, including all appurtenances, of $1.8 \mathrm{~m}$ (length) $\times 1.2 \mathrm{~m}$ (width) $\times 1.2 \mathrm{~m}$ (height), $\pm 0.2 \mathrm{~m}$. Once a package size is selected, the dimension of all packages shall be constant and have a dimensional tolerance of $\pm 0.01 \mathrm{~m}$.

Issue: There is no requirement for all privatization vendors to use the same package design.

Required Analysis: The design of vendor waste packages shall be analyzed for compatibility with storage project package handling equipment and integrated with the transport container and transport vehicle design.

3.2.3.2.3 Mass. The mass of each package shall not exceed $10 ; 000 \mathrm{~kg}$. 


\section{HNF-SD-W465-DRD-001 \\ Revision 1}

3.2.3.2.4 Radiological Composition Documentation. The Contractor shall identify the individual package inventory of radionuclides that are significant as defined in NUREG/BR0204 and 49 CFR 172.101 (Table 2), in the Products and Secondary Wastes Plan. Technetium- $99\left({ }^{99} \mathrm{Tc}\right)$ shall be considered to be significant at concentrations greater than $0.003 \mathrm{Ci} / \mathrm{m}^{3}$ in the ILAW form. The inventories shall be indexed to the year 2000 . The documentation shall be consistent with the Radiological Description format described in NUREG/BR-0204.

3.2.3.2.5 Radionuclide Concentration Limitations. The radionuclide concentration of the ILAW form shall be less than Class C limits as defined in 10 CFR 61.55 and as described in Branch Technical Position on Concentration Averaging and Encapsulation. In addition, the average concentrations of Cesium- $137\left({ }^{137} \mathrm{Cs}\right)$, Strontium-90 $\left({ }^{90} \mathrm{Sr}\right)$, and ${ }^{99} \mathrm{Tc}$ shall be limited as follows: ${ }^{137} \mathrm{Cs}<3 \mathrm{Ci} / \mathrm{m}^{3},{ }^{90} \mathrm{Sr}<20 \mathrm{Ci} / \mathrm{m}^{3}$ and ${ }^{99} \mathrm{Tc}<0.3 \mathrm{Ci} / \mathrm{m}^{3}$. The average concentrations shall be calculated by adding the inventories of each of the above radionuclides in the packages that have been presented to date for acceptance and dividing by the total volume of waste in these packages.

3.2.3.2.6 Surface Dose Rate Limitations. The dose rate at any point on the external surface of the package shall not exceed $1,000 \mathrm{mRem} / \mathrm{h}$.

3.2.3.2.7 Surface Contamination Limitations. Removable contamination on the external surfaces of the package shall not exceed $367 \mathrm{~Bq} / \mathrm{m}^{2}$ for alpha and $3670 \mathrm{~Bq} / \mathrm{m}^{2}$ for beta-gamma contamination when measured using the method described in 49 CFR 173.443(a).

3.2.3.2.8 Labeling and Manifesting. Each package shall have a label attached or stamped on the outer surfaces of at least two sides of the container in a readily accessible location. The label shall contain a unique identification (e.g., serial number) that shall be assigned to each package and the corresponding documentation. Labels and markings shall have a predicted service life of 50 years assuming that the packages are stored in a ventilated enclosure at ambient temperatures.

The Contractor shall prepare a shipping manifest for delivery with each shipment of ILAW product. Information on the manifest shall satisfy the requirements in DOE Order 5820.2A, Chapter III, Section 3.d, and NUREG/BR-0204. Any package containing dangerous waste must be labeled and manifested in accordance with WAC 173-303-370 and the Dangerous Waste Portion of the Resource Conservation and Recovery Act Permit for the Treatment, Storage, and Disposal of Dangerous Wastes (Permit No. WA 7890008967).

3.2.3.2.9 Closure and Sealing. The fully loaded package shall be closed, sealed, and a Tamper Indicating Device applied. The closure system shall be leak tight as defined by ANSI Standard N14.5. The closure system shall be designed to ensure that the seal remains intact for a storage period of 50 years in an ambient-temperature, ventilated enclosure. 
3.2.3.2.10 External Temperature. The temperature of the accessible external surfaces of the package shall not exceed $50 \mathrm{C}$ when returned to DOE. This temperature constraint shall assume a shaded, still air environment at an ambient temperature of $38 \mathrm{C}$.

3.2.3.2.11 Free Liquids. The package shall contain no detectable free liquids as prescribed in ANSI/ANS-55.1 or SW-846 Method 9095.

3.2.3.2.12 Pyrophoricity or Explosivity. The package contents shall not be pyrophoric, readily capable of detonation, or readily capable of explosive decomposition or reaction (including reaction with water) at normal pressure and temperature. The waste form and any optional matrix and filler materials shall not be ignitable or reactive as defined in WAC 173-303-090(5) and WAC 173-303-090(7).

3.2.3.2.13 Explosive or Toxic Gases. The package shall not contain or be capable of generating quantities of explosive (e.g., hydrogen) or toxic gases, vapors, or fumes harmful to persons handling the waste.

3.2.3.2.14 Compressive Strength. The Contractor shall determine the mean compressive strength of the waste form (and any optional matrix and filler materials) by testing representative non-radioactive samples. The compressive strength shall be at least $3.45 \mathrm{E} 6 \mathrm{~Pa}$ when tested in accordance with ASTM C39-94 or an equivalent testing method.

3.2.3.2.15 Compression Testing. Each fully loaded package shall be able to withstand a compression load of $50,000 \mathrm{~kg}$ force. Compliance with this specification shall be established by using the compression test described in 49 CFR 173.465(d). The Contractor shall demonstrate the integrity of the package by showing that the dimensions of the tested packages are within the tolerance range and by showing that the seal remains intact in accordance with Section 3.2.3.2.9.

3.2.3.2.16 Container Material Degradation. The container shall be resistant to degradation by microbial action, moisture, radiation effects, or chemical reactions with the container contents under the expected storage conditions that may reasonably occur during storage (in an ambient-temperature, ventilated enclosure) and handling and disposal operations. The container and handling appurtenances shall be designed to allow safe lifting and movement (in accordance with Section 3.2.3.2.17) after a storage period of 50 years. The integrity of the container shall not be jeopardized by wind, blowing sand, precipitation, sunlight, or extreme temperatures $(+60 \mathrm{C},-40 \mathrm{C})$. Note: The term "container" refers to the waste package, not the shipping container.

3.2.3.2.17 Package Handling. The package shall be compatible with forklift and crane lifting and movement. The package shall be equipped with lifting and other handling appurtenances designed to allow safe lifting, movement, and stacking of the packages when fully loaded. The package shall maintain its integrity during handling, transportation, and stacking. The package shall allow for vertical stacking of six packages. 
3.2.3.3 Nonradioactive Airborne Emissions. A Notice of Construction (NOC) for the emission of toxic air pollutants and/or criteria pollutants must be produced by the operations contractor as required by Ecology (WAC 173-400, "General Regulations for Air Pollution Sources," and WAC 173-460, "Controls for New Sources of Toxic Air Pollutants"). Nonradioactive airborne emission monitoring requirements are located in Section 3.2.3.3.3.

In addition to the NOC requirements, the Air Operating Permit of WAC 173-401 shall be modified to include the ILAW Storage emissions. The ILAW Storage NOC process shall occur before the Air Operating Permit modification process.

3.2.3.3.1 The best available control technology (BACT) and best available control technology for air toxins (T-BACT) shall be used for the construction, installation, or establishment of a new source of nonradioactive emissions subject to those requirements. Air emission calculations shall be performed to support the BACT/T-BACT analysis (WAC 173-400-113 and 173-460-060). BACT for criteria pollutants shall be applied for emissions that exceed the significance levels in 40 CFR 52.21.

3.2.3.3.2 The national primary and/or secondary ambient air quality standards, found in 40 CFR 50.4 through 50.9, shall be met by the ILAW Storage Project.

3.2.3.3.3 The constraints associated with organic emissions, controls, and other nonradioactive airborne emissions, found in 40 CFR 264.1032 and 40 CFR 264.1033 (a, b, c, $\mathrm{g}, \mathrm{h}, \mathrm{k}$ ) shall be met by the ILAW Storage Project.

3.2.3.4 Liquid Effluents. Liquid effluents and leachate generated by the ILAW Storage system shall be transferred to the Liquid Effluent Retention Facility (LERF) and/or the Effluent Treatment Facility (ETF) and shall meet the waste acceptance criteria for these facilities (McDonald 1994).

Issue: The extent of effluent treatment required before discharging the effluents to LERF/ETF needs to be determined by the project.

Required Analysis: Evaluate the expected facility effluent compositions and compare this composition with the LERF/ETF waste acceptance criteria.

3.2.3.4.1 The ILAW Storage liquid effluent waste stream shall be characterized to the degree established in RCRA Part B Permit for the ETF. Analytical procedures shall be consistent with RCRA waste analysis plans. Only the waste codes listed in the Delisting Petition and the RCRA permit shall be accepted for treatment at the ETF, unless the permit and the Delisting Petition are modified.

Basis: Hanford Dangerous Waste Permit Application, 200 Area Effluent Treatment Facility (DOE/RL-93-02) and the 200 Area Effluent Treatment Facility Delisting Petition (DOE/RL-92-72, Rev. 1). The ETF is limited by RCRA regulations to treat only those 


\section{HNF-SD-W465-DRD-001}

\section{Revision 1}

waste streams containing constituents that have been demonstrated to be treatable. The Delisting Petition to the EPA is the primary document controlling what is considered treatable. The delisting petition, if granted, will exclude treated wastes generated from the ETF from RCRA regulation under 40 CFR Parts 262-268 and the permitting standards of Part 270. These documents can be updated to reflect an expansion of the treatment envelope.

3.2.3.5 Solid Waste Management. Solid waste generated by the ILAW Storage system shall be controlled, reduced, segregated, and minimized in accordance with DOE Order 5820.2A, Chapter III, 3.c.E. Transfer of solid radioactive waste to the Hanford Site Solid Waste program for dispositioning shall be in accordance with criteria specified in the Hanford Site Solid Waste Acceptance Criteria, WHC-EP-0063-4 (Willis 1993) and Hazardous Materials Packaging and Shipping, WHC-CM-2-14 (WHC 1993). The exterior of all waste packages shall not be smearable above $220 \mathrm{dpm} / 100 \mathrm{~cm}^{2}$ for alpha and $2,200 \mathrm{dpm} / 100 \mathrm{~cm}^{2}$ for beta-gamma per Hanford Site Solid Waste Acceptance Criteria, WHC-EP-0063-4 (Willis 1993).

3.2.3.6 Radioactive and Mixed Waste Management. A waste management plan, provided by the PHMC, shall be developed for facilities that produce radioactive waste and mixed waste (DOE Order 5820.2A). Hazardous waste shall be regulated in accordance with the Resource Conservation and Recovery Act of 1976 (RCRA) and the Washington Administrative Code (WAC) 173-303, Dangerous Waste Regulations.

3.2.3.6.1 Radioactive Material Packaging. The ILAW Storage Project shall comply with the radioactive waste packaging, shipping, and transportation requirements in DOE Order 1540.2. Radioactive materials properly packaged for transportation from facilities comprising the ILAW Storage shall comply with DOE Order 5480.3. Dose rate limits for radioactive material packaged for onsite transportation are identified in Hanford Radioactive Solid Waste Packaging, Storage, and Disposal Requirements (Stickney 1988) and shall be used for shipment activities.

3.2.3.6.2 Toxic Products and Materials. The design shall include provisions required for handling hazardous materials as identified in DOE Order 5480.3 and WHC-CM-7-5, Chapter 3, Section 3.9.

3.2.3.7 Waste Compatibility. The requirements for waste compatibility are located in "Use and Management of Containers, "WAC 173-303-630, (4) Compatibility.

3.2.3.8 Decontamination and Decommissioning. The design of the storage facility shall facilitate decontamination so that the facility can be decommissioned at a future date. Guidance for process equipment design to facilitate eventual decommissioning shall be obtained from American National Standards Institute (ANSI) N300-1975, Design Criteria for Decommissioning of Nuclear Fuel Reprocessing Plants (ANSI 1975). 


\section{HNF-SD-W465-DRD-001}

Revision 1

3.2.3.9 Closure of Facility. Facility closure will follow one of two possible strategies. The current design baseline is for all waste packages to eventually be retrieved for transport to the ILAW disposal facility once it is in operation. Package handling equipment would be removed and the facility would be backfilled to prevent subsidence. In this case, the storage facility shall be suitable for clean closure after all waste and handling equipment is removed.

An alternate strategy that will be investigated and evaluated during FY 1997 is to leave the waste in place and close the storage facility as a disposal unit. In this case, the space around and above the packages would be backfilled with porous media that could include chemical "getters" to reduce the long-term release rate from the wastes. The decision on whether to follow this strategy will be made as part of the ILAW disposal alternatives generation and analysis process, to be completed by September 30, 1997.

\subsubsection{Physical Characteristics}

Not applicable.

\subsubsection{Protective Coatings. No requirements.}

\subsubsection{Project Quality Factors}

Each system for the ILAW Storage shall meet the reliability, maintainability, and availability requirements consistent with the Tank Waste Remediation System.

3.2.5.1 Reliability. The ILAW Storage design shall provide design features to enhance remote equipment reliability. An evaluation of equipment system failures must be provided to fully define equipment reliability.

Issue: Develop applicable reliability requirements.

Required Analysis: An approved Reliability, Availability, and Maintainability (RAM) analysis must be performed for the ILAW Storage Project.

3.2.5.1.1 Facility Design Life. The facility design life for the storage facility shall be determined by the project and shall support the Tri-Party Agreement (Ecology et al. 1996) milestone M-90-06, "Initiate hot operations of the ILAW interim storage facility" (December 2002). The Facility shall be designed to enable retrieval of stored packages for a period of 50 years from the time of receipt of the first package.

Issue: Selection of the plant design life has implications on the choice of Maintenance and Operations category. A facility design life must be determined taking into consideration economic factors and required Tri-Party Agreement schedules. Individual equipment components must be evaluated separately. 


\section{HNF-SD-W465-DRD-001 \\ Revision 1}

Required Analysis: A documented basis for design life selection must be provided and validated during conceptual design by the project.

3.2.5.2 Maintainability. The ILAW Storage design shall provide for routine maintenance, repair, or replacement of equipment subject to failure. Remote maintenance, inspection, and testing capabilities shall be incorporated where required in the design of the facilities and equipment (DOE Order 6430.1A, Section 1300-3.5). Engineering features (e.g., leachate collection, monitoring, etc.) that ensure compliance with RCRA requirements shall be inspected and maintained in accordance with WAC-173-303.

Issue: Develop applicable maintainability requirements.

Required Analysis: A maintainability plan must be developed and include the use of automatic diagnostic systems (referred to as built-in-test or built-in-test equipment) and external diagnostic systems (referred to as automatic test equipment).

3.2.5.3 Availability. The ILAW Storage plant overall availability (e.g., operational availability) shall be sufficient to produce the required total throughput over the designated life of the plant. Reliability and maintainability analyses shall be conducted for each major equipment development item to obtain availability predictions.

Issue 1: Availability requirements need to be prepared for each equipment system, subsystem, or component.

Required Analysis: An approved Reliability Availability, and Maintainability (RAM) analysis must be performed for the ILAW Storage Project.

Issue 2: A total operating efficiency (TOE) of 60 percent was used to arrive at a throughput and must be evaluated for application to the actual required plant availability.

Required Analysis: An operational availability must be provided during the ILAW Storage conceptual design activities.

3.2.5.4 Operations and Maintenance Considerations. The ILAW Storage design approach shall enhance operations and maintenance to the greatest extent practicable while fulfilling all other design requirements. Operations and Maintenance (O\&M) design requirements relate specifically to the personnel-to-physical plant interface. O\&M qualities of design pertain to the ability of personnel to safely and efficiently interface with the physical plant to perform the intended function. A particular design solution/approach can either enhance, be neutral, or degrade O\&M as opposed to another solution/approach. This section defines and quantifies (as best possible) O\&M considerations to be used for design of the ILAW Storage and is based on a philosophy of "good operating practices." 
HNF-SD-W465-DRD-001

Revision 1

Factors such as life-cycle cost, radioactive waste minimization, and number of personnel and time required to perform plant functions shall be considered in the design. Enhancement of O\&M can be further achieved by incorporation of design features and considerations such as the ones listed below.

3.2.5.4.1 Operations Considerations. The plant shall be designed with operations considerations taken into account. Examples include the following:

- All normally occupied operating stations will be in Radiation Zone 1 (as defined in Section 3.3.1.1) or lower areas, and in Ventilation Zone 3 (as defined in Section 3.3.6.8) or cleaner areas. Other operations may occur in other areas of the facility on a less frequent basis.

- Routine operations will generate as little solid radioactive waste as practical. In particular, the design should be such that little or no manufacturers' packaging material has to be taken into regulated areas of the facility.

- Special precautions (e.g., wearing of masks) will not normally be required for routine operations, except for repair of contaminated equipment, or removal and decontamination of equipment for repair or disposal.

- The overall design philosophy will include minimizing the potential to spread contamination.

3.2.5.4.2 Maintenance Considerations. The plant shall be designed with maintenance considerations such as accessibility, visibility, testability, complexity, and interchangeability taken into account. Examples include the following:

- Personnel performing scheduled routine maintenance shall be in Radiation Zone 2 or lower and in Ventilation Zone 3 or cleaner areas.

- The facility design shall permit scheduled maintenance to be performed without unnecessary disruption of the systems. For example, all routine calibrations and testing of instruments should be accomplished without disconnecting wiring or piping, to the extent practical.

- Routinely used spare parts and materials shall be stored readily at hand to assist in maintaining continuous operations.

- Equipment should be standardized to the maximum extent practical to reduce spare parts inventories and training requirements. 
HNF-SD-W465-DRD-001

\section{Revision 1}

- All required inspections within radiation Zone 3 or higher, or in Ventilation Zone 1 shall be performed remotely, unless the area is designed to be readily decontaminated.

- Where scheduled inspections of large equipment are required, built in features for inspection should be provided so that special equipment, such as cranes, does not have to be brought in from offsite.

3.2.5.4.3 Occupancy Requirements. The estimated facility occupancy is shown in Table 3-1. The facility shall be designed to comfortably accommodate the single shift population. Locker rooms shall be sized to accommodate the total occupancy for craft, operators, and technicians.

Table 3-1. Occupancy Requirements.

\begin{tabular}{|l|c|c|}
\hline \multicolumn{1}{|c|}{ Classification } & $\begin{array}{c}\text { Maximum single } \\
\text { shift }\end{array}$ & Total personnel \\
\hline Manager & 3 & 5 \\
\hline Engineer & 3.5 & 4.5 \\
\hline Professional & 3 & 4 \\
\hline Technician & 2 & 9.5 \\
\hline Craftsman & 6 & 9 \\
\hline Operator & 4 & 15 \\
\hline General Office & 2.5 & 3 \\
\hline Total & 24 & 50 \\
\hline
\end{tabular}

\subsubsection{Environmental Conditions}

The ILAW storage structures, systems and components shall be designed to withstand the temperature, pressure, and humidity environments based on the most severe postulated accident affecting the particular item. The postulated environment shall reflect an environment that considers both radiological composition (e.g., elements, isotopes, total radioactivity) and chemical composition (e.g., abrasives, acids, smoke, caustic vapors) of all material physical forms likely to affect the equipment (DOE 6430.1A Div. 1300-3.4.2). 


\section{HNF-SD-W465-DRD-001 \\ Revision 1}

Each system for the ILAW Storage shall be designed to meet the requirements for exposure to the following natural and induced environmental conditions:

3.2.6.1 Natural Environments. The following meteorological parameters shall be used, as necessary, during the ILAW Storage conceptual design activities:

3.2.6.1.1 Temperature. The temperatures and conditions at the Hanford Meteorological Station (HMS) are expected to be similar to the conditions at the project site in the 200 East Area. The systems for this ILAW Storage Project shall be designed to operate at or near these temperatures and conditions provided by the HMS.

The mean surface air temperature averages approximately $12 \mathrm{C}(53 \mathrm{~F})$ at the HMS. July tends to be the warmest month of the year with temperatures averaging $25 \mathrm{C}(76 \mathrm{~F})$. The average daily minimum and maximum temperatures for July are $16 \mathrm{C}$ and $33 \mathrm{C} \mathrm{(61} \mathrm{and}$ 92 F) respectively. The highest temperature ever recorded on the Site was 46 C (115 F). January is the coolest month of the year with an average temperature of $-2 \mathrm{C}(29 \mathrm{~F})$. The lowest temperature ever recorded on the Site was -33 C (-27 F).

The Hanford Site and vicinity is known for severe and abrupt temperature changes. During winter the site frequently experiences rapid rises in temperature accompanied by moderate west winds. This phenomenon, known as a chinook wind, has produced variations of up to $12 \mathrm{C}(22 \mathrm{~F})$ in 0.5 hours.

During much of the year, a well-defined nocturnal temperature inversion occurs over the Hanford Site. The inversion is strongest in early fall and spring when the minimum nighttime temperature at the top of the inversion may be 5 to $8 \mathrm{C}(9$ to $14 \mathrm{~F})$ warmer than at the basin floor.

3.2.6.1.2 Relative Humidity. The systems for this project should be designed to operate in a humidity range as recorded at the HMS. Relative humidity at the HMS is expected to be representative of that in the 200 East area.

The annual mean relative humidity recorded at the HMS is approximately 54 percent with the highest monthly relative humidity ( 80 percent) occurring in December and the lowest average monthly relative humidity ( 32 percent) occurring in July. Daily relative humidity can change 20 to 30 percent between early morning and late afternoon, except in the winter months when the changes are less pronounced.

3.2.6.1.3 Precipitation. The ILAW storage systems shall use the precipitation conditions recorded by the HMS for design calculations, as necessary. The mean annual precipitation at the HMS is approximately $16 \mathrm{~cm}(6.3 \mathrm{in}$.). Historical data indicate that over a period of roughly 80 years, the annual precipitation varied from a low of $8 \mathrm{~cm}(3.1 \mathrm{in}$.) to a high of $30 \mathrm{~cm}(11.8 \mathrm{in}$.$) . Precipitation of 4 \mathrm{~cm}(1.56 \mathrm{in}$.) in a 24 hour period can be expected to occur once every 25 years. Total annual snowfall has varied from $0.8 \mathrm{~cm}$ to $110 \mathrm{~cm}(0.31$ 


\section{HNF-SD-W465-DRD-001}

\section{Revision 1}

in. to $43.3 \mathrm{in}$.), with an average annual snowfall of $34 \mathrm{~cm}(13.4 \mathrm{in}$.). The largest depth of snow on the ground at one time was $62 \mathrm{~cm}(24.4 \mathrm{in}$.) Small hail, diameters from 5 to $10 \mathrm{~mm}$ ( 0.2 to $0.4 \mathrm{in}$.), has been recorded at HMS, with two days of hail being the most in any one year.

\subsubsection{Induced Environments.}

3.2.6.2.1 Radiation. ILAW storage structures, systems and components shall be capable of performing their intended function for the duration of their intended useful life with no adverse effects due to the radiological and chemical environment in the system(s) that they operate.

\subsubsection{Transportability}

Material handling systems such as overhead bridge cranes shall be designed for ease of removal and replacement in the vaults by remote means. Cranes shall be transportable from one vault to another. The design shall provide for remotely operated removal and reinstallation of bridge crane and trolleys using temporary cranes and trucks for transporting the equipment. Crane rails and power systems internal to the vault do not need to be transportable.

\subsubsection{Flexibility and Expansion}

The process and facility design shall accommodate changes in the flowsheet throughout the operating life of the facility by a built-in capability to change process equipment (e.g., process flexibility). Design solutions shall demonstrate methods for modification, expansion, additional capacities (unless otherwise restricted in other requirement sections), and other techniques when justified on a life-cycle cost basis.

The degree of flexibility will be determined during conceptual design. Typically, the following flexibility features are provided:

- Remote equipment installation and removal and the decontamination and decommissioning (D\&D) capabilities for remotely maintained equipment and facilities

- Ability to convert the filled storage vault to a disposal configuration. Design features of the disposal configuration will be based on performance assessment criteria.

Basis: DOE Order 6430.1A, section 0110-3 states: "Flexibility is a major design requirement for all facilities except those with highly specialized functions. Even in those special facilities, however, the design shall, to the maximum extent 


\section{HNF-SD-W465-DRD-001}

\section{Revision 1}

practicable, provide sufficient flexibility to accommodate for programmatic changes or operational modifications."

\subsubsection{Portability}

Not applicable.

\subsection{DESIGN AND CONSTRUCTION}

DOE Order 6430.1A provides general design criteria for the acquisition of the DOE facilities. The general design criteria specified in DOE Order 6430.1A (primarily applicable Division 13 and applicable parts of Section 99) shall be used for the design and construction of the ILAW Storage, Project W-465. Additional specific requirements are identified in the following sections.

\subsubsection{Materials (i.e., Structure, Shielding)}

The structure and layouts of the facility shall conform to applicable HPS, DOE Order 6430.1A (DOE 1989), National Fire Protection Association codes, and the Uniform Building Code (UBC 1994).

Issue: Seismic requirements for the storage of ILAW in the modified facility may differ from those used in the original design of the vaults.

Required Analysis: The modified vaults and ancillary structures will require structural and seismic analysis to determine the impacts of the modifications on the structural integrity and operational safety envelope.

3.3.1.1 Facility Design and Shielding Criteria. Guidelines for radiological design are provided in Radiological Design Guide, WHC-SD-GN-DGS-30011 (WHC 1994b). The shielding design criteria in Table 3-2 are summarized from Radiological Design Guide, Section 7.0, and shall be used to determine the shielding requirements of different areas in the facility. Shielding shall be designed to limit the total whole body dose to less than $5 \mathrm{mSv}$ per year. 
HNF-SD-W465-DRD-001

Revision 1

Table 3-2. Storage Facility Shield Design Criteria.

\begin{tabular}{|c|c|c|c|}
\hline Zone category & Access time allowed & $\begin{array}{c}\text { Maximum } \\
(\mu \mathrm{Sv} / \mathrm{h})\end{array}$ & $\begin{array}{c}\text { Maximum } \\
(\mathrm{mrem} / \mathrm{h})\end{array}$ \\
\hline Uncontrolled area & Full time & 0.5 & 0.05 \\
\hline Controlled Area & \multicolumn{3}{|l|}{} \\
\hline 1 & Full time & 2.5 & 0.25 \\
\hline 2 & Less than $1 \mathrm{~h} /$ day & 20 & 2.0 \\
\hline 3 & Less than $1 \mathrm{~h} /$ week & 100 & 10.0 \\
\hline 4 & Less than $10 \mathrm{~h} /$ year & 500 & 50.0 \\
\hline 5 & No normal access permitted & $>500$ & $>50$ \\
\hline
\end{tabular}

Note: For design purposes the dose due to neutrons should be calculated by doubling the neutron quality factors (DOE Order 5480.11).

3.3.1.2 Transportation Shielding Criteria. The transport container system shall provide sufficient shielding to comply with DOT radiological protection guidelines in addition to the guidelines shown in Table 3-2. A loaded transport container shall not exceed the criteria for contact handling. Transportation system shielding criteria are summarized in Table 3-3.

Table 3-3. Transportation Shielding Criteria.

\begin{tabular}{|l|l|l|}
\hline Basis for limit & \multicolumn{1}{|c|}{$\begin{array}{c}\text { Maximum dose } \\
\text { rate }(\mu \mathrm{Sv} / \mathrm{h})\end{array}$} & $\begin{array}{l}\text { Maximum dose rate } \\
(\mathrm{mrem} / \mathrm{h})\end{array}$ \\
\hline $\begin{array}{l}\text { Contact } \\
\text { Handling }\end{array}$ & $\begin{array}{l}2000 \text { at container } \\
\text { surface }\end{array}$ & $\begin{array}{l}200 \text { at container } \\
\text { surface }\end{array}$ \\
\hline DOT Cargo & 100 at 2 meters & 10 at 2 meters \\
\hline DOT Driver & 20 at truck cab & 2 at truck cab \\
\hline
\end{tabular}

3.3.1.3 Support Structure(s) and Systems. Support services in the form of backup power, uninterruptible power supply (UPS), regulated process facility entry, maintenance and repair, supply and exhaust air, process ventilation system, fire water system, solid waste handling, and the collection and handling of radioactive and non-radioactive liquid wastes shall be provided as part of the facility. All support functions and infrastructure identified in Table 3-4 are included in the project scope. The ILAW Storage Project shall include the support services indicated as "dedicated" in Table 3-4. 


\section{HNF-SD-W465-DRD-001}

\section{Revision 1}

Table 3-4. Support Function Definition. (Table derived from early draft of TWRS Process Support and Infrastructure Definition) (2 sheets)

\begin{tabular}{|c|c|c|}
\hline Function description & Location/provider & Shared versus dedicated \\
\hline $\begin{array}{l}\text { Collect and handle potentially radioactive } \\
\text { liquid waste }\end{array}$ & $\begin{array}{l}\text { Leachate Collection/ILAW } \\
\text { Storage }\end{array}$ & Dedicated \\
\hline Storage facility fire water system & $\begin{array}{l}\text { Water pumphouse/TWRS } \\
\text { Infrastructure }\end{array}$ & Shared \\
\hline Storage facility ventilation system & ILAW Storage & Dedicated \\
\hline Supply air treatment system & ILAW Storage & Dedicated \\
\hline Exhaust air treatment system & ILAW Storage & Dedicated \\
\hline Collection and handling of solid wastes & ILAW Storage & Dedicated \\
\hline Backup power system & $\begin{array}{l}\text { Switchgear building/ILAW } \\
\text { Storage }\end{array}$ & Dedicated \\
\hline Uninterrupted power system & $\begin{array}{l}\text { Telecommunications } \\
\text { room/LAW Storage }\end{array}$ & Dedicated \\
\hline Personne1 Protection System & ILAW Storage & Dedicated \\
\hline Maintenance and repair & $\begin{array}{l}\text { Maintenance Facility/Site } \\
\text { Infrastructure }\end{array}$ & Shared \\
\hline Sanitary and raw water system & $\begin{array}{l}\text { Water pumphouse/TWRS } \\
\text { Infrastructure }\end{array}$ & Shared \\
\hline Sanitary sewer system & Control building/ILAW Storage & Dedicated \\
\hline $\begin{array}{l}\text { Tank Waste Remediation System } \\
\text { treatment complex site fire water system }\end{array}$ & $\begin{array}{l}\text { Water pumphouse/TWRS } \\
\text { Infrastructure }\end{array}$ & Shared \\
\hline $\begin{array}{l}\text { Heating, venting and air conditioning } \\
\text { system }\end{array}$ & Control Building/IIAW Storage & Dedicated \\
\hline Compressed air system & $\begin{array}{l}\text { Maintenance building/LAW } \\
\text { Storage }\end{array}$ & Dedicated \\
\hline Normal AC power system & $\begin{array}{l}\text { Switchgear building/ILAW } \\
\text { Storage }\end{array}$ & Dedicated \\
\hline $\begin{array}{l}\text { Storage Process facility operations } \\
\text { control system }\end{array}$ & Control building/LAW Storage & Dedicated \\
\hline Major equipment assembly & $\begin{array}{l}\text { Maintenance building/LAW } \\
\text { Storage }\end{array}$ & Dedicated \\
\hline Spare parts fabrication & $\begin{array}{l}\text { Maintenance building/LAW } \\
\text { Storage }\end{array}$ & Dedicated \\
\hline Telecommunications system & $\begin{array}{l}\text { Telecommunications } \\
\text { room/LAW Storage }\end{array}$ & Dedicated \\
\hline Reguiated facility entry & Controi building/ILAW Storage & Dedicated \\
\hline
\end{tabular}


Table 3-4. Support Function Definition. (Table derived from early draft of TWRS Process Support and Infrastructure Definition) (2 sheets)

\begin{tabular}{|l|l|c|}
\hline \multicolumn{1}{|c|}{ Function description } & \multicolumn{1}{|c|}{ Location/provider } & Shared versus dedicated \\
\hline Treatment Complex Management System & Control building/LAW Storage & Dedicated \\
\hline Employee Support System & Control building/LAW Storage & Dedicated \\
\hline $\begin{array}{l}\text { Shipping and Receiving System, } \\
\text { Warehousing and Storage System, } \\
\text { Service Yard }\end{array}$ & LAW Storage & Dedicated \\
\hline
\end{tabular}

LAW = Immobilized Low Activity Waste.

Basis: TWRS Process Support and Infrastructure Definition (Leach 1995). Letter 95-RTI-034, G. Sanders, DOE, to President, WHC, Common Support and Infrastructure for Tank Waste Remediation System (TWRS) (Sanders 1995).

Issue: The support system definitions and identification as a shared or dedicated function is the subject of the trade study TWRS Process Support and Infrastructure Definition. All functions have been derived from this study and must be updated to reflect the final conclusions of the report.

Required Analysis: PHMC release of the trade study TWRS Process Support and Infrastructure Definition. The definition of the common support and infrastructure facilities will be a consolidated effort amongst the architect engineers, during conceptual design, for the respective TWRS processing facilities.

3.3.1.3.1 Collection and Handling of Potentially Radioactive Liquid Waste. The ILAW Storage Project shall provide collection and handling of potentially radioactive liquid effluents. The system shall be capable of sampling potentially contaminated effluent streams and directing them to suitable retention facilities.

3.3.1.3.2 Storage Facility Fire Water System. A fire water system shall be provided to the ILAW Storage facility. The fire protection system shall meet the requirements of applicable NFPA, National Fire Codes, DOE Order 5480.7A, RLID 5480.7 and DOE Order $6430.1 \mathrm{~A}$.

3.3.1.3.3 Storage Facility Ventilation System. A separate ventilation system shall be provided by the ILAW Storage project for the storage vaults. The storage facility ventilation system shall maintain a ventilated, ambient temperature environment in the vaults. The ventilation system shall provide intake and exhaust filtration to prevent entry of windblown dust and debris. 


\section{Revision 1}

Issue: The facility is presumed to be an uncontaminated facility. The storage facility ventilation system is not intended to provide contamination control nor is it intended to meet the requirements of DOE Order 5400.5, Radiation Protection of the Public and Environment.

Required analysis: Product acceptance specifications and procedures shall be reviewed and maximum credible accident analyses shall be performed to determine the consequences of an accidental uncontrolled release of the ILAW. product in the vault.

3.3.1.3.4 Supply Air Treatment System. The Supply Air Treatment System shall provide filtration for removal of windblown dust and debris into the vaults.

3.3.1.3.5 Exhaust Air Treatment System. The Exhaust Air Treatment System shall provide filtration to prevent the entry of windblown dust and debris into the vaults. The exhaust air systems shall be fitted with continuous air samplers to automatically shut down the ventilation system if an uncontrolled release of radioactive material is detected.

3.3.1.3.6 Collect and Handle Solid Waste. This system will be a dedicated system provided by the ILAW Storage Project. The requirements for solid waste management are found in Section 3.2.3.5.

3.3.1.3.7 Backup Power System. If required per the Preliminary Safety Analysis Report, any backup power System shall be provided by the ILAW Storage and meet the applicable requirements of $6430.1 \mathrm{~A}$. The backup power system shall provide power to those functions required to maintain operation and bring the ILAW storage facility into a safe shutdown condition in the event of a loss of normal AC power.

3.3.1.3.8 Uninterruptible Power Supply System. The ILAW Storage shall provide a UPS system close to the equipment items requiring UPS support. The UPS system provides continuous power to equipment requiring continuous power during short duration power outages. The system consists of rectifiers/battery chargers, invertors, switching components and batteries.

3.3.1.3.9 Personnel Protection System. The Personnel Protection System is a dedicated internal system provided by the ILAW Storage project. The Personnel Protection System provides for worker safety within the ILAW Storage facilities. This system includes emergency exits, fire walls, shield walls, alarms, radiation monitors, air samplers, and other items required to assure worker safety. This system will be used by all personnel working at the ILAW storage facilities.

3.3.1.3.10 Maintenance and Repair. The ILAW Storage Project shall provide for the maintenance and repair of failed equipment. The system consists of repair areas, tools, and equipment necessary to remove, maintain, and repair failed product handling and 


\section{HNF-SD-W465-DRD-001 \\ Revision 1}

transportation equipment. The ILAW storage maintenance and repair function will be shared with the Hanford site infrastructure.

3.3.1.3.11 Sanitary Water System. Sanitary water systems shall be shared utilities with the other TWRS processing functions and shall be provided via a shared water pumphouse allocated to the TWRS treatment and disposal projects. Sanitary (potable) water shall be separated from raw (nonpotable) water and fire water by the design criteria as stated in DOE Order 6430.1A. Sanitary water shall be used to supply the storage facilities water needs (e.g., domestic water).

3.3.1.3.12 Sanitary Sewer System. The sanitary sewer shall be routed to a shared collection and handling system provided by the TWRS infrastructure project. The system discharges the domestic sewage to the 200 Area Sanitary Sewer System. The portion of the sanitary sewer system within the ILAW Storage shall be designed for a 7-day, 24-h, 3 workshift basis, and shall be sized for the maximum number of people on 1 shift.

3.3.1.3.13 Storage Facility Fire Water System. This system will be a shared system provided by the TWRS infrastructure project and consists of the water pumphouse and main fire loop.

3.3.1.3.14 Heating, Ventilation, and Air Conditioning (HVAC) System. A dedicated HVAC system, or systems, shall be provided by the ILAW Storage Project to ensure safe operation of the facility. The HVAC system shall be designed to maintain the comfort of personnel in the control room, maintenance building, locker rooms and other normally occupied areas. The HVAC system shall meet applicable requirements in DOE Orders 6430.1A, General Design Criteria (DOE 1989) and other applicable federal, state, and local regulations.

3.3.1.3.15 Compressed Air System. The Compressed Air System shall be a dedicated system provided by the ILAW Storage Project. The system provides instrument air for pneumatically controlled components, plant air for general maintenance use and breathing air, including breathing air from bottles as needed.

3.3.1.3.16 Normal AC Power System. The normal AC power system will distribute AC power throughout the TWRS Treatment Complex and originates at an offsite $230 \mathrm{kV}$ switchyard with a capacity to serve multiple facilities. Power will be distributed from the switchyard at $34.5 \mathrm{kV}$ to intermediate substations dedicated to various TWRS complexes. A single substation will be located at the TWRS Waste Treatment Complex (Switchgear Building) to transform the $34.5 \mathrm{kV}$ feed to $13.8 \mathrm{kV}$ normal AC power. The Waste Pretreatment Facilities shall utilize unit substations to transform the $13.8 \mathrm{kV}$ distribution to utilization voltages of 13.8 and $4.151 \mathrm{kV}$, and $480 \mathrm{~V}$, depending on specific needs. All electrical devices shall conform to National Electrical Code (NFPA 70). 
3.3.1.3.17 Storage Facility Operating Control System. The ILAW Storage Project shall provide a distributed control system (DCS) to interface with storage facility equipment and the central control room. The centralized control system monitors and controls remote operations, closed-circuit television (CCTV) systems, and inventory control systems.

The DCS shall be a special-purpose, functionally distributed, microprocessor-based system with hierarchical functions supervised or handled by the host computer in the central control room. The interface requirements to the central control system will be defined as part of the ILAW Storage project conceptual design. The design of the DCS shall comply with these interface requirements.

The DCS shall monitor and control the storage facility operations, HVAC, and support services; provide product inventory control; and process manual requests and data input. Standard vendor-supplied software shall be used and shall be capable of calling up real-time displays and historical data. The distributed microprocessors shall have execution speeds, scan rares, transmission rates, and loadings appropriate to ensure control of the facility or process.

The installed spare capacity of system hardware such as input, output, memory, peripheral, and additional DCS devices shall be a minimum of 25 percent.

3.3.1.3.18 Major Equipment Assembly. Major equipment assembly will be a dedicated system provided by the ILAW Storage project. This system provides for the assembly of new, in-vault equipment before installation in the storage facilities.

3.3.1.3.19 Spare Parts Fabrication. The Spare Parts Fabrication function is a shared (not distance constrained) function provided by the project. The spare parts fabrication function shall provide for the manufacturing and assembly of small equipment items and spare parts required for the operation and maintenance of the ILAW Storage facilities and Transport equipment.

3.3.1.3.20 Telecommunications System. The telecommunications system is a dedicated system and shall be provided by the ILAW Storage Project. The system consists of all equipment required to provide internal and external communications functions. The external telecommunications system will provide for telephone, emergency response, and data transfer into and out of the facility, including multiple connections to the Hanford LAN system, while the internal telecommunications system will provide for communications within the facility. This system includes voice, video, spectrum-dependent communications and data communications required to support facility operations, maintenance, management and emergency response.

Land based trunk lines will enter the storage facility at a single location and be routed to the telecommunications room in the central control building. Distribution equipment will then route both hard wired and wireless communications to the various areas of the facility. 


\title{
HNF-SD-W465-DRD-001
}

Revision 1

3.3.1.3.21 ILAW Storage Management System. The Treatment Complex Management System is a dedicated system provided by the ILAW Storage Project. This system provides facilities for the management and support of the ILAW Storage operations. This system provides office space for operations and support personnel as well as facilities for postal service, plant records retention, reprographics, training, and public outreach displays.

3.3.1.3.22 Employee Support System. This system is a dedicated system provided by the ILAW Storage Project. The Employee Support System provides for amenities required to enhance worker comfort and morale. This system consists of lunch rooms, vending machines, toilet facilities, and items aimed at enhancing the work environment.

3.3.1.3.23 Shipping and Receiving System, Warehousing, and Storage System, and Service Yard. This system is a system provided by ILAW Storage. The Shipping and Receiving System provides for the receipt, inspection, and inventory control of waste packages, equipment, spare parts, and miscellaneous goods being delivered to the ILAW Storage facilities. The system also provides for the packaging and distribution of these items to the various process and process support facilities within the ILAW Storage facilities.

3.3.1.3.24 Vault Access. Access shall be provided for transporting waste packages to the vaults. This will require upgrades of existing roads and construction of new roads as required to allow transport vehicles access to the vaults for unloading. Roadways will be upgraded according to specifications as determined by the site development plan. Section 0250-3 of DOE Order 6430.1A specifies geometry and gradients be designed in accordance with American Association of State Highway and Transportation Officials (AASHTO) GDHS84, which has been superseded by A Policy on Geometric Design of Highways and Streets (AASHTO). Pavements design is specified to conform with Washington State Department of Transportation (WSDOT), Standard Specifications for Road, Bridge and Municipal Construction, M 41-10-94, and WSDOT Design Manual, M 22-01. Signing, pavement markings and channelization shall comply with the Manual on Uniform Traffic Control Devices for Streets and Highways, ANSI 6.1 (ANSI) and DOE Order 6430.1A. Roadway lighting shall comply with IES Lighting Handbook HB-93 and ANSI C 136 series (ANSI). Electrical installation related to traffic control devices and roadway lighting shall be in accordance with National Electrical Code, NFPA-70 (NFPA).

For roads and miscellaneous site grading, materials shall consist of native and imported materials meeting the following WSDOT specifications:

\author{
9-02, Bituminous Materials \\ 9-05, Drainage Structures, Culverts and Conduits \\ 9-14, Erosion Control and Roadside Planting \\ 9-16, Fence and Guardrail \\ 9-28, Signing, Materials and Fabrication \\ 9-29, Illumination, Signing, Electrical.
}




\section{HNF-SD-W465-DRD-001 \\ Revision 1}

\subsubsection{Electromagnetic Radiation}

No requirements.

\subsubsection{Nameplates and Product Marking}

Hanford Site standards developed for identification of nameplates and product markings shall be followed and are specified in Data Standards Administration, WHC-CM-2-6 (WHC 1994a).

3.3.3.1 Equipment and Piping. Labelling. DOE Order 5480.19, Conduct of Operations Requirements for DOE Facilities, Chapter XVIII, item C specifies requirements for equipment and piping labelling. DOE Standard 1044-93, "Guide to Good Practices for Equipment and Piping Labeling;" DOE Order 6430.1A, Section 1300-12.4.11, "Labels." Labeling of electrical raceways and circuits shall be in accordance with ANSI-Y14.15.

\subsubsection{Workmanship}

See Section 4.0.

\subsubsection{Interchangeability}

The ILAW Storage Project shall include interchangeability factors. These requirements are TBD. Interchangeability is necessary to allow, as much as is practical, for temporary use of different parts/equipment until a replacement is procured, e.g., use of a pipe fitting or electrical fitting that may suffice until its replacement is obtained.

\subsubsection{Safety}

Requirements and guidance on safety documentation are located in DOE Orders 6430.1A, 5480.7A, 5480.22, and 5480.23. Safety documentation includes Facility Hazards Classification, Preliminary and Final Safety Analysis Reports, Fire Hazards Analysis, and Technical Safety Requirements. These reports will be supplied by the PHMC. The requirements for developing a Safety Equipment List are located in WHC-CM-4-46, Safety. Analysis Manual, Standard 9.0, Safety Structure, Systems, and Components, Section 4.2. Requirements and guidance on industrial safety and hygiene are located in WHC-CM-1-10, WHC-CM-1-11, and WHC-CM-4-40.

3.3.6.1 Design Basis Accidents. The project shall be designed to withstand the effects of design basis accidents (DBAs), as defined in DOE Order 6430.1A, General Design Criteria (DOE 1989), without loss of containment and with confinement of radioactive and toxic materials within allowable limits. Simultaneous occurrences of more than one DBA shall be considered when a joint occurrence (i.e., common-mode failure) is possible. The DBAs shall 


\section{HNF-SD-W465-DRD-001 \\ Revision 1}

include (but not be limited to) fire, power failure, earthquake, tornado, flood, and ash fall. The specifications for this ILAW product preclude criticality from being a credible accident scenario.

3.3.6.1.1 Design Basis Fire. The storage facility shall be designed to withstand a design basis fire in accordance with DOE Order 6430.1A, DOE Order 5480.7A, "Fire Protection," and applicable NFPA standards. The design basis fire shall be considered to be that fire that results from the burning of all combustible materials enclosed within a continuous barrier rated at a minimum of 2 hours.

3.3.6.1.2 Design Basis Power Failure. The storage facility shall withstand a design basis power failure consisting of total loss of power for one minute and loss of normal power for 24 hours.

3.3.6.1.3 Design basis Earthquake. The storage facility shall be designed to withstand a design basis earthquake in accordance with DOE Order 6430.1A and ICFKH STD GCLOAD-01, "Design Loads for Facilities.

3.3.6.1.4 Design Basis Tornado. The storage facility shall be designed to withstand a design basis tornado in accordance with ICFKH STD GC-LOAD-01.

3.3.6.1.5 Design Basis Flood. The elevation of the storage facility site has been judged to be outside the maximum extent of the Hanford Site design basis flood. Therefore no flood analysis is required.

3.3.6.1.6 Design Basis Ash Fall. The storage facility shall be designed to withstand a design basis ash fall in accordance with ICFKH STD GC-LOAD-01. Designs shall be analyzed to determine the effects on the heating, ventilation and air conditioning systems, mechanical and electrical equipment, structures, and personnel operations that could result from the abrasive or chemical properties of volcanic ash.

3.3.6.2 Nuclear Safety/Criticality. The ILAW product specification precludes the possibility of a criticality occurring.

3.3.6.3 Classification of Structures, Systems, and Components. The project design shall comply with the Management Requirements and Procedures, WHC-CM-1-3, "Safety Classification of Systems, Components, and Structures, "and WHC-CM-4-46, Non-Reactor Facility Safety Analysis Manual.

3.3.6.3.1 Safety Classification. All structures, systems, and components shall be designated according to the criteria and methodology, which are based on potential consequence of failure. 
Revision 1

3.3.6.4 Component Failure Analysis. The design shall be such that no single credible component failure or loss of normal power will result in unacceptable safety consequences. Unacceptable safety consequences include the following:

- Fire (other than localized minor fire such as caused by shorting of electrical equipment)

- Explosion

- Instantaneous release of radioactivity from the facility in excess of 5,000 times the derived concentration guide (DCG) values specified in WHC-CM-7-5, Environmental Compliance, Appendix C (WHC 1994b) at point of discharge

- Exposure of personnel to ionizing radiation in excess of DOE Order 5480.11, Radiation Protection for Occupational Workers (DOE 1988)

- Exposure of personnel to toxic chemical agents in excess of ceiling threshold limit (CTL) value of the American Conference of Governmental Industrial Hygienists.

The effects of component failure, including control and monitoring, and utilities failure (such as power sources, air and vacuum supplies) shall be evaluated for unacceptable consequences.

3.3.6.5 Abnormal Operations. The facility design shall include provisions to monitor and alarm on detection of abnormal conditions such as radioactive particulate release, liquid intrusion, gaseous release, abnormal radiation levels, fires, and overheating or pressurization. Process and facility systems shall be designed to ensure safe channeling of energy and material flows (e.g., rupture discs, fault-to-ground electrical circuitry, etc.).

3.3.6.6 Personnel Radiation Exposure. Personnel radiation exposure shall be in accordance with ALARA principles, cost benefit analysis, and DOE Orders 5400.5 Chapter II (item 2), and 5820.2A.

3.3.6.7 Ventilation Systems. This system shall be designed in accordance with DOE Order 6430.1A, DOE Order 5480.11, DOE Order 5400.5, and the Radiological Design Guide (WHC 1994b). Sufficient redundancy and/or spare capacity shall be provided as necessary to ensure adequate ventilation during normal operations and DBA conditions.

3.3.6.8 Ventilation Zones. The ILAW packages shall be free from external contamination, as described in Section 3.2.3.2.7. Therefore, confinement ventilation is not required for the ILAW storage facility. All areas of the storage facility will be classified "Neutral Zone" (see Table 3-5) with respect to confinement ventilation. Confinement shall be provided by the storage structure, as required by DOE Order 6430.1A, Section 1324-6. The storage area shall be ventilated to maintain an "ambient temperature, ventilated enclosure" storage environment. 


\section{HNF-SD-W465-DRD-001}

\section{Revision 1}

as described in Section 3.2.3.2.16. The discharge from the ventilation systems shall be fitted with continuous air samplers to automatically shut down the ventilation system if an uncontrolled release of radioactive material is detected.

Table 3-5. Ventilation Zones.

\begin{tabular}{|l|l|l|}
\hline \multicolumn{1}{|c|}{ Zone } & \multicolumn{1}{|c|}{$\begin{array}{c}\text { Minimum DP } \\
\text { (in. WG) }\end{array}$} & \multicolumn{1}{|c|}{ Description of typical areas } \\
\hline I -Process Zone & -1.0 & High and potentially high contamination areas. \\
\hline II - Control Zone & -0.5 & $\begin{array}{l}\text { Areas providing access or penetrations to Zone I. Not } \\
\text { normally contaminated areas with moderate } \\
\text { contamination potential. May be normally or } \\
\text { frequently occupied areas. }\end{array}$ \\
\hline III - Operating Zone & -0.25 & $\begin{array}{l}\text { Not normally contaminated areas with low } \\
\text { contamination potential. Normally or frequently } \\
\text { occupied areas. }\end{array}$ \\
\hline IIIA - Operating Zone & -0.1 & $\begin{array}{l}\text { Less contamination potential than Zone III. Minimum } \\
\text { DP may not be maintained with outer doors open. }\end{array}$ \\
\hline IV - Uncontrolled Access Zone & +0.125 & $\begin{array}{l}\text { Clean areas. Areas where contamination is } \\
\text { unacceptable. }\end{array}$ \\
\hline Neutral Zone & N/A & Areas not requiring confinement ventilation. \\
\hline
\end{tabular}

$\mathrm{DP}=$ Differential Pressure with respect to atmospheric pressure

N/A = Not Applicable

WG = Water Gage.

Final airborne particulate treatment on all airborne effluents that have the potential to exceed 10 percent of the derived concentration guide-public value on an annual average basis as cited in Environmental Compliance, WHC-CM-7-5 (WHC 1994b), shall use a highefficiency particulate air (HEPA) or equivalent filter.

The adequacy of the filtration system (the number of filtration stages required) shall be determined by analysis to ensure the contamination in the effluents are ALARA and do not exceed the above emission limits.

Design shall provide for measurement of supply and exhaust airflows. Final HEPA filter systems, if required, shall include the necessary fire protection provisions to comply with DOE Orders 6430.1A and 5480.7.

3.3.6.9 Remote Maintenance. Requirements for remote maintenance are located in DOE Order 5820.2A. 


\section{HNF-SD-W465-DRD-001 \\ Revision 1}

3.3.6.10 Fire Protection. The requirements for fire protection shall be in accordance with DOE Orders 5480.4, 5480.7A, RL directives RLID 5480.7, WHC-CM-4-41, the NFPA National Fire Codes (including NFPA 101 and 241), and the Uniform Fire Code to the extent that is implemented by WAC 173-303.

The design for the Fire Protection and Detection System shall comply with the requirements of DOE Order 6430.1A.

The facility shall comply with 29 CFR 1926 and 29 CFR 1910 and NFPA 101. Conformance with NFPA shall be considered to satisfy the site requirements of 29 CFR 1910. (DOE Order 6430.1A, Section 0110-6.1)

3.3.6.11 Occupational Health and Safety. DOE Order 5483.1A, 29 CFR 1910, and 29 CFR 1926 contain health and safety requirements that shall be used for this project. Engineering controls shall be used where feasible to prevent or minimize exposure to hazards.

\subsubsection{Human Engineering}

The system shall be designed to be comfortable and natural for humans to operate and maintain. Design considerations shall be given to the guidelines in Mil-Std 1472D, Human Engineering Design Criteria for Military Systems, Equipment, and Facilities (DOD 1989) and DOE Order 6430.1A, Section 1300-12, Human Factor Engineering.

\subsubsection{Nuclear Control}

Not applicable.

\subsubsection{Security}

Exterior telecommunications and alarm systems shall be designed in accordance with DOE Order 6430.1A. See requirement 3.3.1.3.20, Telecommunications.

\subsubsection{Government Furnished Property Usage}

Not applicable.

\subsubsection{Computer Resource Reserve Capacity}

Computer requirements are provided in 3.3.1.3.17. 
HNF-SD-W465-DRD-001

Revision 1

\subsection{INFORMATION AND PROJECT DOCUMENTATION}

Records, documents, and document control pertinent to design functions shall be in accordance with ASME-NQA-1-1994-1A, DOE 5500.7b, DOE-4700.1, and ANSI/ANS-3.2-88.

\subsubsection{Drawings}

All AE/CM drawings prepared for the system shall comply with the Hanford Plant Standards when released to PHMC at completion of Title III (construction inspection).

\subsubsection{Technical Manual}

Manuals describing the technical operations and maintenance aspects of all equipment provided by the ILAW Storage Project shall be prepared and provided to the operating and maintenance contractor. Vendor supplied equipment manuals are acceptable as technical manuals.

\subsection{LOGISTICS}

Logistic elements shall be included in the ILAW Storage Project. These requirements are TBD. Logistics can be viewed as the composite of all considerations necessary to assure the effective and economical support of a system throughout its life cycle. Logistic elements shall be developed on an integrated basis with other segments of the system.

Logistic elements to be considered include the following:

- Maintenance--Operations and Maintenance plans, equipment documentation, repair manuals, etc.

- Supply System requirements--requirements for supply lines, specialized parts/equipment needed to support this mission.

\subsection{PERSONNEL AND TRAINING}

The system shall be designed for operation by personnel possessing qualifications in accordance with DOE 5480.20, Chapter IV, and trained in accordance with Chapter I.

\subsection{CHARACTERISTICS AT SUBORDINATE ELEMENTS}

No requirements identified at this time. 
HNF-SD-W465-DRD-001

Revision 1

\subsection{PRECEDENCE}

The hierarchical relationship among requirements specified in section 3 is as follows, excepting those instances where Washington State has been granted regulatory authority by the U.S. Government:

Federal Laws (e.g., Code of Federal Regulations)

Revised Code of Washington (RCW) as specified in Washington Administrative Codes (WAC)

Local Ordinances

U.S. Department of Energy Orders

National Consensus Codes and Standards.

\subsection{QUALIFICATION}

The ILAW Storage design shall include provisions for periodic testing of monitoring, surveillance, and alarm systems. In addition, design shall provide the capability to test periodically, under simulated conditions, safety class items that are required to function under emergency conditions. Safety class items shall be designed to be tested on a regular schedule (DOE Order 6430.1A, Section 1300-3.6) as required.

\subsection{STANDARD SAMPLE}

Not applicable.

\subsection{PREPRODUCTION SAMPLE, PERIODIC PRODUCTION SAMPLE, PILOT OR PILOT LOT}

Not applicable. 
HNF-SD-W465-DRD-001

Revision 1

This page intentionally left blank. 
HNF-SD-W465-DRD-001

Revision 1

\subsection{QUALITY ASSURANCE PROVISIONS}

The ILAW Storage Project shall adhere to the applicable requirements of 10 CFR 830.120, "Nuclear Safety Management, Subpart A, General Provisions, Section 830.120, Quality Assurance Requirements, " Code of Federal Regulations, as implemented on the Hanford Site by WHC-SP-1131, "Quality Assurance Program and Implementation Plan." The project shall develop a project specific Quality Assurance Program Plan (QAPP) that will include the following elements, as applicable:

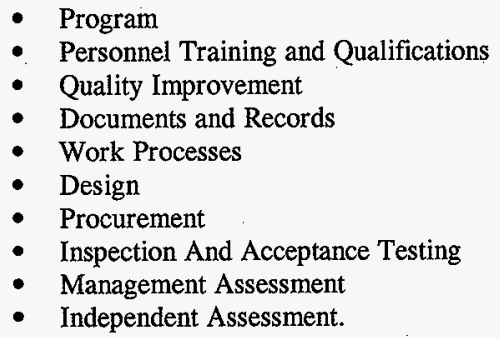

Once the QAPP has been approved at the PHMC project level, the document shall be submitted to DOE for their approval.

All subcontractors providing services for the ILAW Storage Project, (i.e., A-E services, Construction Management (CM) services, and testing services in support of technology development) shall have or shall be required to develop a QA program that complies with the requirements of the project QAPP for the subcontractors area of responsibility. Nationally recognized consensus standards (i.e., NQA-1, ISO 9000, 10 CFR 50, Appendix B) may be used as guidance in development of a QA program, though no single standard fully meets all the requirements of 10 CFR 830.120. All subcontractor QA programs shall be submitted to the PHMC ILAW Storage Project for review and concurrence.

\subsection{RESPONSIBILITY FOR INSPECTION}

Not applicable.

\subsection{SPECIAL TESTS AND EXAMINATIONS}

Tanks and vessels shall be designed using ASME, Section VIII. 
HNF-SD-W465-DRD-001

Revision 1

\subsection{REQUIREMENTS CROSS REFERENCE}

Not applicable. 
HNF-SD-W465-DRD-001

Revision 1

\subsection{PREPARATION FOR DELIVERY}

Not applicable.

\subsection{NOTES AND REFERENCES}

\subsection{INTENDED USE}

Not applicable.

\subsubsection{Missions}

Not applicable.

\subsubsection{Hazards}

Not applicable.

\subsection{LIST OF TERMS}

$\mathrm{AE} / \mathrm{CM}$

AGA

ALARA

ANSI

ASHRAE

ASME

ASTM

BACT

CFR

$\mathrm{CM}$

CMAA

D\&D

DBA

DCG

DCS
Architect-Engineer/Construction Manager

Alternatives Generation and Analysis

As low as reasonably achievable

American National Standards Institute

American Society of Heating, Refrigeration, and Air-Conditioning

Engineers

American Society of Mechanical Engineers

American Society for Testing Materials

Best available control technology

Code of Federal Regulations

Controlled manual

Crane Manufacturer's Association of America

Decontamination and decommissioning

Design basis accident

Derived concentration guide

Distributed control system 
HNF-SD-W465-DRD-001

Revision 1

\section{LIST OF TERMS (CONTINUED)}

$\begin{array}{ll}\text { DOE } & \text { U.S. Department of Energy } \\ \text { DOE-RL } & \text { U.S. Department of Energy-Richland Operations Office } \\ \text { DOH } & \text { Washington State Department of Health } \\ \text { DP } & \text { Differential pressure } \\ \text { DRD } & \text { Design Requirements Document } \\ \text { EDE } & \text { Effective dose equivalent } \\ \text { EHSC } & \text { Environmental hazard safety classification } \\ \text { EPA } & \text { U.S. Environmental Protection Agency } \\ \text { ETF } & \text { Effluent Treatment Facility } \\ \text { FDC } & \text { Functional Design Criteria } \\ \text { FEMP } & \text { Facility Effluent Monitoring Plan } \\ \text { HLW } & \text { High-level waste } \\ \text { HMS } & \text { Hanford Meteorological Station } \\ \text { HPS } & \text { Hanford Plant Standards; health protection system } \\ \text { HVAC } & \text { Heating, ventilating, and air-conditioning } \\ \text { ICD } & \text { Interface Control Document } \\ \text { IHLW } & \text { Immobilized high-level waste } \\ \text { ILAW } & \text { Immobilized low-activity waste } \\ \text { LERF } & \text { Liquid Effluent Retention Facility } \\ \text { LETF } & \text { Liquid Effluent Treatment Facility } \\ \text { LAW } & \text { Low-activity waste } \\ \text { LLW } & \text { Low-level waste } \\ \text { NFPA } & \text { National Fire Protection Association } \\ \text { NOC } & \text { Notice of Construction } \\ \text { NRC } & \text { Nuclear Regulatory Commission } \\ \text { O\&M } & \text { Operations and maintenance } \\ \text { OSHA } & \text { Occupational Safety and Health Administration } \\ \text { PHMC } & \text { Project Hanford Management Contractor } \\ \text { QAPP } & \text { Quality Assurance Program Plan } \\ \text { RCRA } & \text { Resource Conservation and Recovery Act of 1976 } \\ \text { RL } & \text { U.S. Department of Energy, Richland Operations Office } \\ \text { RLID } & \text { U.S. Department of Energy, Richland Operations Office, Implementing } \\ & \text { Directive } \\ \text { RLIP } & \text { U.S. Department of Energy, Richland Operations Office Implementing } \\ \text { SDC } & \text { Procedure } \\ \text { SDRD } & \text { Standard Arch-Civil Design Criteria } \\ \text { SEWP } & \text { Supplemental Design Requirements Documents } \\ \text { SST } & \text { Systems Engineering Working Plan } \\ \text { T-BACT } & \text { Single-shell tank } \\ \text { TBD } & \text { Test available control technology for air toxins } \\ \text { TEDF } & \end{array}$


HNF-SD-W465-DRD-001

Revision 1

\section{LIST OF TERMS . (CONTINUED)}

Tri-Party
Agreement
TRU
TRS
TSD
TWRS
WAC
WHC
WISHA

Tri-Party

TRU

TRS

TSD

WAC

WISHA

\author{
Hanford Federal Facility Agreement and Consent Order \\ Transuranic \\ Technical Requirements Specification \\ Treatment, storage, and disposal \\ Tank Waste Remediation System \\ Washington State Administrative Code \\ Westinghouse Hanford Company \\ Washington Industrial Safety and Health Act
}

\subsection{DEFINITIONS}

Availability-Availability is a measure of the degree to which an item is in an operable and committable state at any point in time. Mathematically, there are several ways availability can be calculated, depending on the desired use. Conceptually, availability is Up Time divided by Total Time (Total Time $=$ Up Time + Down Time). As with reliability, there are different types of availability, such as inherent availability, operational availability, and achieved availability.

Design Requirements Document (DRD)--The design requirements baseline is documented by project-level design requirements documents (DRDs), associated interface control documents, and functions and requirements. This documentation captures all of the functions, interfaces, and requirements that are allocated to a specific architectural solution, and will provide a basis for design by an $\mathrm{A} / \mathrm{E}$. (The design basis includes all results of formal decision analysis, technical analyses, studies, and other products of systems engineering that are used to provide a rationale for baseline requirements.)

Functions and Requirements--The functions are statements of purpose, defining what the system must do; requirements indicate how well the function must be accomplished. The Tank Waste Remediation System F\&Rs are detailed to the fourth level of the architecture in DOE/RL-92-60, Tank Waste Remediation System Functions and Requirements (RL 1994).

Hazardous Waste--At the Hanford Site, this term usually means nonradioactive chemical toxins or otherwise potentially dangerous materials such as sodium, heavy metals, beryllium, or some organics.

High-Level Waste--The highly radioactive waste material that results from the reprocessing of spent nuclear fuel, including liquid waste produced directly in reprocessing and any solid waste derived from the liquid, that contains a combination of transuranic waste and fission products in concentrations requiring permanent isolation (DOE Order 5820.2A, Radioactive Waste Management [DOE 1988]). 


\section{HNF-SD-W465-DRD-001}

\section{Revision 1}

Immobilization--A process (e.g., grouting or vitrification) used to stabilize waste. Stabilizing the waste inhibits the release of waste to the environment.

Leachate--Any liquid, including suspended components in the liquid, that has percolated through or drained from hazardous or solid waste. Also refers to liquid that percolates out of a solution.

Low-Activity Waste--The waste that remains after separating from high-level waste as much of the radioactivity as is practicable that when solidified may be disposed of as low-level waste in a near surface facility according to U.S. Nuclear Regulatory Commission regulations. In its final form, it would meet Class $\mathrm{C}$ radioisotope limits.

Logistics Reliability--This is the measure selected to account for or address all incidents that require a response from the logistics system.

Low-Level Waste--Any gaseous, liquid, or solid waste that contains radioactivity and is not classified as high-level waste, transuranic waste, or spent nuclear fuel or byproduct material as defined by DOE Order 5820.2A, Radioactive Waste Management (DOE 1988). Test specimens of fissionable material irradiated for research and development only, and not for the production of power or plutonium, may be classified as low-level waste, provided the concentration of transuranic is $<100 \mathrm{nCi} / \mathrm{g}$.

Maintainability--Maintainability is a characteristic of design and installation expressed as the probability that an item will be retained in, or restored to, a specific condition within a given period of time, when maintenance is performed in accordance with prescribed procedures and resources.

Maintenance--Maintenance is defined as all actions required to retain or restore the system to a specified condition. This may include diagnosis, repair or inspection.

Mission Reliability--Mission reliability is the probability that a system will perform missionessential functions for a period of time under the conditions stated in the mission profile. Reliability measures are concerned with the expected frequency of failure.

Operating Life--The operating life is the time span from hot startup through processing of the final feed.

Operational Availability--Operational availability is defined as operating time divided by total calendar time. 
Revision 1

Reliability--Reliability is defined as the probability that an item will perform its intended function for a specified interval under stated conditions. This definition does not specifically consider the effect of the age of the system. Reliability can be further subdivided into mission reliability and logistics reliability. Reliability measures are concerned with the expected frequency of failure.

\subsection{REFERENCES}

ASME, 1989, Quality Assurance Program Requirements for Nuclear Facilities, ASME NQA-1-1989, American Society of Mechanical Engineers, New York, New York.

Bernero, R. M., 1993, United States Nuclear Regulatory Commission, letter to Ms. Jill Lytle, Deputy Assistant Secretary for Waste Operations Office of Waste Management, Environmental Restoration, and Waste Management.

Burbank, D. A., 1996, Alternatives Generation and Analysis Report for Immobilized LowLevel Waste Interim Storage Architecture, WHC-SD-W465-AGA-001, Rev. 0, Westinghouse Hanford Company, Richland, Washington.

DOE, 1987, Final Environmental Impact Statement, Disposal of Hanford Defense High-Level Transuranic and Tank Wastes, Hanford Site, Richland, Washington, DOE/EIS-0113, U.S. Department of Energy, Washington, D.C.

DOE, 1994, Tank Waste Remediation Systems (TWRS) Systems Engineering Management Plan, DOE/RL-93-0106 (Annex 2), U.S. Department of Energy, Richland, Washington.

DOE, 1995, Draft Environmental Impact Statement for the Management of Spent Nuclear Fuel from the K Basins at the Hanford Site, Richland, WA, DOE/EIS-0245D, U.S. Department of Energy, Richland, Washington.

DOE, 1996, Tank Waste Remediation System, Hanford Site, Richland, Washington, Final Environmental Impact Statement, DOE/EIS-0189, U.S. Department of Energy and Washington State Department of Ecology, August, 1996, Richland, Washington.

Ecology, EPA, DOE, 1996, Hanford Federal Facility Agreement and Consent Order, sixth amendment, Washington State Department of Ecology, U.S. Environmental Protection Agency, and U.S. Department of Energy, Olympia, Washington.

Jacobs, 1995, Engineering Calculations for the Tank Waste Remediation System Environmental Impact Statement, Jacobs Engineering Group, Kennewick, Washington. 


\section{Revision 1}

Johnson, M. E., 1994, Tank Waste Remediation System Decisions and Risk Assessment, WHCEP-0786, Westinghouse Hanford Company, Richland, Washington.

Leach. C. E., 1995, TWRS Process Support and Infrastructure Definition, WHC-SD-W378-ES-002, Rev. 0, Westinghouse Hanford Company, Richland, Washington.

McDonald, F. N., 1994, Acceptance of Feed Streams for Storage and Treatment at the LERF/ETF Complex, WHC-SD-ETF-WAC-001, Rev. 0, Westinghouse Hanford Company, Richland, Washington.

Orme, R. M., 1994, TWRS Process Flowsheet, WHC-SD-WM-TI-613, Rev. 0, Westinghouse Hanford Company, Richland, Washington.

Resource Conservation and Recovery Act of 1976, 42 USC 6901 et seq.

Sanders, G., 1995, Common Support and Infrastructure for Tank Waste Remediation System (TWRS), Letter 95-RTI-034, to President, WHC (May 4), U.S. Department of Energy, Richland, Washington.

Stickney, R. G., 1988, Hanford Radioactive Solid Waste Packaging, Storage, and Disposal Requirements, WHC-EP-0063, Westinghouse Hanford Company, Richland, Washington.

Wagoner, J. D., 1995, Request for Proposals (RFP) No. DE-RP06-96RL13308, Letter 96-RTI029 to Prospective Offerors, February 20,1996, as amended, U.S. Department of Energy, Richland, Washington.

WHC, 1994a, Tank Waste Remediation System Multi-Year Work Plan, WHC-SP-1101, Vol. 1, UC-600, Westinghouse Hanford Company, Richland, Washington.

WHC, 1994b, Radiological Design Guide, WHC-SD-GN-DGS-30011, Westinghouse Hanford Company, Richland, Washington.

WHC, 1996, Tank Waste Remediation System Functions and Requirements Document, WHC-SD-WM-FRD-020, Westinghouse Hanford Company, Richland, Washington.

Willis, N. P., 1993, Hanford Site Solid Waste Acceptance Criteria, WHC-EP-0063-4, Westinghouse Hanford Company, Richland, Washington. 